\title{
DOS DIREITOS DO EMPREGADO DOMÉSTICO. INCOERÊNCIA DA INTERPRETAÇÃO RESTRITIVA EM FACE DO CONTEÚDO PRINCIPIOLÓGICO CONSTITUCIONAL
}

\author{
DOMESTIC EMPLOYEES RIGHTS. INCOHERENCE OF THE RESTRICTIVE INTERPRETATION \\ CONSIDERING THE CONSTITUTIONAL PRINCIPLES
}

\section{Roberto Benavente Cordeiro}

\begin{abstract}
Resumo:
O objetivo do presente trabalho é analisar a interpretação majoritariamente conferida à legislação especial destinada a regular a relação de emprego doméstica, demonstrando sua incompatibilidade com o os princípios e fundamentos estampados na vigente Constituição da República Federativa do Brasil, mormente com relação aos princípios da igualdade, dignidade da pessoa humana e valor social do trabalho, sugerindo-se uma nova exegese, harmônica com tais vetores.
\end{abstract}

Palavras-Chaves: Empregado doméstico. Proteção. Constituição Federal. Interpretação. Isonomia. Dignidade humana.

\begin{abstract}
:
The aim of this article is to analyse the majoritarian interpretation given to the domestic employees legal regime, showing its lack of compatibility before Constitutional Principles, mainly regarding the human dignity, social value of labour and the isonomy axioms. Besides, it is suggested a new line of interpretation, which would be harmonic with the aforementioned principles.
\end{abstract}

Keywords: Labour employee. Protection. Federal Constitution. Interpretation. Isonomy. Human Dignity.

\section{Introdução}

A ordem constitucional brasileira ora vigente é baseada em uma série de princípios e valores que retratam a constante preocupação do constituinte em proteger a integridade do ser humano, não apenas física, como também moral. A Constituição da República Federativa do Brasil constitui, portanto, importante marco legislativo para a proteção dos cidadãos.

Assim é que são consagrados na Lei Maior princípios como o da igualdade de todos os indivíduos perante a lei, e o da valorização social do trabalho. Tais vetores, por sua vez, representam vertentes que se destinam à concretização de um dos fundamentos

1 Especialista em Direito do Trabalho e Seguridade Social pela Faculdade de Direito da Universidade de São Paulo, Juiz do Trabalho do TRT $-3^{\text {a }}$ Região. 
de nosso Estado Democrático, nos moldes constitucionais, qual seja o de proteção da dignidade da pessoa humana.

Esses princípios e valores, de certo, interferem na produção legislativa, na atividade jurisdicional e também na interpretação dos preceitos normativos componentes da ordem jurídica. Todos esses misteres devem se adequar àquele conteúdo principiológico, sob pena de quedarem ineficazes juridicamente, em decorrência do vício de inconstitucionalidade que os eivaria.

Entretanto, assim como todo e qualquer princípio, os acima referidos não vigoram na ordem jurídica pátria de forma absoluta. Merecem certa relativização, com vistas a se alcançar harmonia entre as normas vigentes, ou seja, de modo a permitir a incidência de outros princípios, valores e regras cuja observância também se faz necessária em determinado caso concreto.

Para que seja reputada válida tal relativização, contudo, esclarece-se que é necessária a existência de efetiva e real justificativa. Em outras palavras, torna-se justa a diferenciação de um indivíduo em relação ao outro, apenas quando efetivamente existente um motivo concreto para tanto. Apenas nesses termos é que uma determinada situação de discriminação não viria a afetar os ideais de proteção da pessoa humana presentes na Constituição.

Em sede de relações de emprego, por força principiológica constitucional, do ideário de isonomia, é vedada qualquer diferenciação de tratamento entre trabalhadores em função da atividade desempenhada. Todos merecem a devida proteção, adequada às peculiaridades do labor em que atuam.

Nesse sentido, para que receba um obreiro tratamento jurídico diferenciado, ou proteção distinta da conferida aos demais empregados, indispensável é a existência de peculiaridades laborais justificadoras de tal desequiparação.

Com base em tal linha de raciocínio se apresenta dominante, tanto na doutrina como na jurisprudência, o posicionamento de que os empregados domésticos, por desempenharem atividade em condições especiais, diversas das do empregado comum, atuante em âmbito empresarial, merece tratamento distinto desses, de modo que inadequada seria a extensão, a tais trabalhadores, de certas proteções asseguradas em lei.

Como decorrência, construiu-se, ao longo dos tempos, e antes da promulgação do atual texto constitucional, arcabouço legislativo que restringe o leque de direitos conferidos à classe de trabalhadores domésticos. Posteriormente, com a promulgação da nova Lei Maior, a despeito de relativa evolução, manteve-se aquele conceito de forma 
imperativa, tanto que seu conteúdo conduziu para esse mesmo sentido a interpretação constitucional, no que toca às regras de proteção dessa classe de trabalhadores.

Todavia, entendemos que a atual exegese realizada de forma uníssona sobre o regime jurídico conferido aos empregados domésticos não-abarca acolhida na atualidade, mormente em face do conteúdo principiológico constitucional que ora inspira a ordem jurídica. É exatamente sobre esse descompasso interpretativo que buscaremos dissertar ao longo do presente estudo.

Buscar-se-á, para tanto, então, diagnosticar inicialmente quais as principais características qualificadoras da relação de emprego doméstico. Analisaremos, posteriormente, a evolução legislativa da proteção conferida ao empregado doméstico, atingindo o status em que é majoritariamente vislumbrado seu rol de direitos na atualidade. Nesse momento, intentar-se-á detalhar com precisão a diferença entre o tratamento jurídico que é dispensado à classe doméstica e aos demais empregados.

Feita tal análise, passar-se-á a tentar apontar a pertinência, a adequação das peculiaridades da relação especial de emprego em tela, bem como dos argumentos comumente expostos pela doutrina e jurisprudência, enquanto legitimadores da discriminação implementada.

Posteriormente, destinar-se-átal trabalhoàcomprovaçãodaincompatibilidade desse entendimento diferenciador com os princípios permeadores da ordem constitucional em voga. Isso posto, passar-se-á a defender a construção de uma nova interpretação constitucional, baseada em tais valores dantes demonstrados, exegese essa que possibilite a equiparação do regime jurídico conferido aos domésticos com aquele dispensado aos demais empregados.

Antes de iniciado tal estudo, entretanto, consideramos válida, até como medida destinada a buscar raízes culturais, pretéritas do problema em questão, a realização de uma análise dos antecedentes históricos do trabalho doméstico. É o que se passa a efetuar.

2. Antecedentes históricos do trabalho doméstico

Duas são as principais vertentes pelas quais é analisada a origem histórica do trabalho doméstico.

A primeira considera que tal modalidade laborativa decorre de uma colocação antigamente valorizada e disputada e que, portanto, ensejava consideráveis honrarias e privilégios a quem nelas empregava sua energia de trabalho. 
Sustentando tal corrente, Aloysio Santos assevera que "o trabalho doméstico, ao contrário do que muitos pensam, era exercido nas cortes de reis e grão senhores como tarefa nobilitante, tanto que na época medieval, pajens e escudeiros dispunham de graus de escala honorifica das ordens de cavalaria, e que ser aia de uma dama de estirpe era honraria disputadissima". ${ }^{2}$

Por outro lado, é majoritariamente vista a raiz do atual labor doméstico na servidão, bem como na prática escravagista.

Assim é que indícios históricos apontam já na Idade Antiga, mais especificamente em Roma, o desempenho das tarefas do lar como incumbência dos servos urbanos familiares. Igualmente, na Grécia, cuja sociedade era segregada em castas, quais sejam as citadinas, vassalas e escravas, por essa última é que aqueles serviços eram desempenhados. ${ }^{3}$ Nesse contexto, de forma totalmente diversa daquele ponto de vista acima exposto, por se tratar de préstimo reservado aos escravos, era o trabalho doméstico encarado por gregos e romanos como um encargo, uma penalidade.

Ao longo desse período histórico, por decorrer de regime de servidão ou escravidão, o trabalho doméstico, obviamente, não garantia ao obreiro qualquer contraprestação. Sequer contrato de prestação de serviços era celebrado. Ao senhor era reservada, exclusivamente, a incumbência de manter, sustentar os subordinados. Tal situação permaneceu inalterada ao longo da Idade Média.

Nesse período, aliás, toma destaque a predominância, quase que em caráter absoluto, da servidão doméstica desempenhada por mulheres, às quais eram atribuídas as tarefas do lar, bem como as de trato dos filhos dos senhores, e a de fazer companhia às esposas daqueles. Ao lado das mulheres, comum era a participação, em tais misteres, dos filhos dos servos, "crianças normalmente entre 9 e 17 anos que, como aprendizes, eram entregues às famílias dos senhores feudais para servirem em suas residências; estes, os senhores, em contrapartida, encarregavam-se da formação social da criança". ${ }^{4}$

No Brasil, igualmente, o trabalho doméstico encontra raízes na escravidão, principalmente do trabalho desempenhado pelos escravos negros, compelidos a laborar nas residências dos colonizadores, conforme se estabeleciam esses em território pátrio. Mesmo após a abolição da escravatura, ausente qualquer perspectiva desses antigos escravos conquistarem trabalho assalariado, permaneciam laborando para os ex-senhores,

2 SANTOS, Aloysio. Manual de contrato de trabalho doméstico. 2. ed Rio de Janeiro: Forense, 1998. p. 09.

3 NORMANDO, Claudia Cavalcante. Trabalho doméstico: valores jurídicos e dignidade humana. 1. ed. Porto Alegre: Sergio Antonio Fabris Editor, 2005. p. 46.

4 Id. Ibid., p. 47. 
em troca de moradia e alimentação, ou seja, do mínimo necessário para a subsistência. Sob o ponto de vista legal, obrigatória era a remuneração pelo serviço prestado. Todavia, ineficaz no plano concreto se apresentava tal regra.

Com o advento do regime capitalista de produção, e o avanço da Idade Média para a Idade Moderna, o labor servil é substituído pelo assalariado. Com a Revolução Industrial, as mulheres acabam absorvidas pelo mercado de trabalho. Passam a ocupar postos de serviços nas fábricas, abandonando seus lares, e deixando-os, quando existente condição financeira para tanto, sob administração de uma trabalhadora doméstica. Destaca-se, contudo, que desde então, passa o labor doméstico a ser acompanhado de contraprestação pelo serviço prestado. Torna-se assalariado, pois. Entretanto, continuava a ser desempenhado apenas por aquelas mulheres que não encontrassem colocação nas indústrias. Em outras palavras, permaneciam acompanhadas as tarefas do lar do estigma de antes, qual seja, o de atividade indesejada, flagelante.

O contexto pós-industrial, por sua vez, fez crescer de forma considerável o número de pessoas ingressantes no mercado de trabalho doméstico. Isso porque a constante automação procedida nas indústrias, demandante de especialidade técnica para a operação das máquinas, mas desacompanhada de reciclagem do conhecimento dos trabalhadores, fez com que esses não mais se mostrassem capazes de assumir os postos de trabalho dantes ocupados, e passassem a buscar colocações em outros setores laborais, dentre os quais, o ora em análise. Por tais motivos é que se verifica a crescente criação de agências de emprego doméstico, bem como de sindicatos profissionais representes da categoria dos empregados domésticos. ${ }^{5}$

Guardada a devida vênia com relação ao primeiro dos acima ilustrados enfoques referentes às raízes do labor doméstico, parece-nos que a evolução histórica da sociedade permite, de fato, diagnosticar que esse guarda estreitas origens com o trabalho servil e escravo. Por tal motivo, continua a ser visto, mormente em âmbito cultural brasileiro, pela maioria dos indivíduos, como um ônus indesejado, como trabalho estritamente ligado ao escravo. Tanto o referido é verdade que o crescimento da mão de obra disponível nesse campo não decorreu, como visto, do reconhecimento de sua importância social, mas sim de pura e simples carência de colocação em outros setores econômicos.

E de fato, como bem observa Maria Helena Xavier Mendes Fróes, "com o passar dos tempos, não obstante a influência da igreja, bem como da indústria, dentre outros fatores, podemos concluir que o enfoque dado ao problema da regulamentação do

5 NORMANDO, Claudia Cavalcante. Trabalho doméstico: valores jurídicos e dignidade humana. 1. ed. Porto Alegre: Sergio Antonio Fabris Editor, 2005. p. 53. 
doméstico, decisivamente, deveu-se ao desenvolvimento da estrutura social e política de cada país, o que faz com que na Europa, por exemplo, hoje em dia, lhes sejam concedidos mais direitos, enquanto que na América Latina ele ainda seja alvo de uma legislação bastante tímida". ${ }^{6}$

Nessas linhas é que se desenvolveu historicamente o labor doméstico.

\section{Características da relação empregatícia doméstica}

Nos termos do artigo $7^{\circ}$, "a" da CLT, são considerados domésticos os trabalhadores "que prestam serviços de natureza não econômica a pessoa ou família, no âmbito residencial destas".

Melhor aprofundando tal conceito, a Lei n. 5.859/72 define empregado doméstico como "aquele que presta serviços de natureza contínua e de finalidade não lucrativa à pessoa ou à família, no âmbito residencial destas".

Destas definições, extraem-se como características marcantes do emprego doméstico, ao lado das tradicionais onerosidade e subordinação, comuns a qualquer relação empregatícia, a pessoalidade, a continuidade da prestação de serviços, a inexistência de lucratividade no labor desempenhado, e o âmbito residencial em que se desenvolve. Tais traços serão melhor detalhados e explanados em seguida.

\subsection{Da pessoalidade}

A pessoalidade é atributo inerente a qualquer contrato de trabalho. Consubstancia-se no fato de a prestação de serviços ser desempenhada pessoalmente pelo empregado contratado, e não por sujeitos dele diversos.

Nota-se, portanto, que em âmbito de emprego doméstico, o contrato celebrado também se mostra como intuitu personae com relação ao empregador. Melhor esclarecendo, descaracterizado estaria o vínculo empregatício se ao obreiro fosse facultado, habitualmente, se fazer substituir por outro indivíduo na prestação de serviços.

Como bem observa Cláudia Cavalcante Normando, em sua obra "Trabalho Doméstico: Valores Jurídicos e Dignidade Humana”, a pessoalidade no trabalho doméstico adquire especial relevância, visto que "a pessoa contratada transporta não somente sua força de trabalho, mas também um senso relacional psicológico especial, que envolve a

${ }_{6}$ FRÓES, Maria Helena Xavier Mendes. Trabalho doméstico. Revista Direito, Estado e Sociedade, Rio de Janeiro, n. 16, p. 01-25, 2000. 
família do empregador, posto que a relação familiar é íntima, expressiva e formadora da personalidade de seus membros". ${ }^{7}$

Vale ressaltar, como o faz a majoritária doutrina, que a demanda de pessoalidade na relação de emprego doméstica não faz com que essa seja qualificada por traços de benevolência, no sentido de que o empregador aceitaria o trabalhador doméstico em seu lar por questões de solidariedade, que por sua vez ensejariam a inserção desse na vida familiar do empregador.

A relação de emprego doméstico, na verdade, é permeada também pelas tradicionais características de qualquer vínculo empregatício. É, portanto, onerosa, e envolve obrigações recíprocas de ambas as partes. Não há que se falar, então, em benevolência do empregador, vez que esse se apresenta, como qualquer outro sujeito, como titular de deveres no pacto laboral.

\subsection{Da continuidade}

A continuidade é requisito essencial à caracterização de relação empregatícia doméstica, no que pertine à necessidade de o serviço ser prestado de forma não-eventual.

Controvertida é a interpretação empregada sobre o termo "continuidade". Isso porque, a Lei n. 5.859/72 deixa de trazer especificação própria de seu teor. Divergem a doutrina e a jurisprudência, então, entre dois possíveis sentidos.

O primeiro deles não vislumbra diferença entre os conceitos de continuidade e habitualidade, prevista no art. $3^{\circ}$ da CLT. Assim sendo, desenvolvido o trabalho de modo não-eventual, independentemente da freqüência, da permanência, da quantidade de dias laborados por semana, se for esse habitual, configurada quedaria a relação empregatícia doméstica. Como bem observa Maurício Godinho Delgado, seguida tal linha de raciocínio, concluir-se-ia que desde que presente o labor em caráter não-eventual, também a Lei n. 5.859/72 teria rejeitado a teoria da descontinuidade, definindo como empregado a figura do diarista doméstico. ${ }^{8}$

Já a segunda corrente verifica na referida expressão conteúdo diverso do da tradicional habitualidade demandada para a configuração de relação de emprego comum. Nesse sentido, a continuidade induziria à idéia de algo ininterrupto, seguido, sucessivo, duradouro, mesmo que não-diário.

\footnotetext{
7 NORMANDO, Claudia Cavalcante. Trabalho doméstico: valores jurídicos e dignidade humana. 1. ed. Porto Alegre: Sergio Antonio Fabris Editor, 2005. p. 55

8 DELGADO, Maurício Godinho. Curso de direito do trabalho. 4. ed. São Paulo: LTr, 2005. p. 368
} 
O ordenamento jurídico trabalhista da Argentina, consoante o que leciona o já recorrido e insigne professor Sergio Pinto Martins, parece adotar tal corrente de entendimento, vez que, nas palavras do suscitado autor, segundo a legislação daquele país "não se consideram domésticos os trabalhadores que prestem serviços por tempo inferior a um mês, os que laborem menos de quatro horas diárias ou que trabalhem menos de quatro dias na semana, para o mesmo empregador". 9

Em âmbito pátrio, a jurisprudência atual do TST demonstra que tal colegiado vem acolhendo de forma uníssona a tese sustentada pela última das correntes acima expostas. Assim é que, recentes decisões vêm reconhecendo vínculo de emprego apenas quando o trabalhador doméstico se ativa, para o mesmo empregador, por cerca de no mínimo três vezes por semana. É o que se extrai da apreciação do julgado abaixo mencionado, cuja ementa passa-se a transcrever, in verbis:

DIARISTA - VÍNCULO EMPREGATÍCIO - AUSÊNCIA
DO REQUISITO DA CONTINUIDADE. Pretende o
Reclamante o reconhecimento do vínculo empregatício
doméstico, em razão dos serviços prestados à Reclamada no
máximo duas vezes por semana, que compreendiam "levar
a reclamada de carro, uma vez por mês, ao médico, duas
vezes por semana ao dentista, ao supermercado e a passeios
esporádicos, além de sair para passear com a cachorrinha,
ir ao supermercado, comprar revistas e lavar o carro." (fls.
51). A Lei n. 5.859/72, que dispõe sobre a profissão de
empregado doméstico, exige deste a prestação de serviços
"de natureza contínua", no âmbito residencial da pessoa ou
família. A controvérsia cinge-se a estabelecer se o serviço
realizado duas vezes por semana atende ao requisito da
continuidade exigido pela Lei. A jurisprudência firma-se no
sentido de não considerar contínuo o trabalho efetuado em
poucos dias na semana, consoante se extrai dos precedentes
transcritos. Recurso conhecido e desprovido. (TST, RR
- 119-2002-47-03-00. Órgão Julgador: Terceira Turma.
FONTE: DJ. Data: 13-02-2004. Relatora: Ministra Maria
Cristina Irigoyen Peduzzi)

A despeito do entendimento sustentado pelo Colendo Tribunal Superior do Trabalho, parece-nos mais coerente a primeira das correntes supramencionadas. Isso porque, não há como não se considerar contínuo um trabalho desenvolvido, mediante subordinação, mesmo que apenas em uma ocasião semanal, mas durante longo intervalo de tempo. Em outras palavras, mesmo que não desempenhado em todos os dias da semana,

9 MARTINS, Sergio Pinto. Direito do trabalho. 17. ed. São Paulo: Atlas, 2003. p. 149. 
queda considerado como contínuo o trabalho ativado em dias certos da semana, em horário prefixado, ou seja, em contexto no qual o empregado não disponha de plena autonomia no tocante à fixação dos dias e horários de trabalho.

Raciocinando-se analogicamente, mostra-se possível inclusive traçar paralelo entre a situação do empregado comum, inserido em regime de tempo parcial, nos moldes do art. 58-A da CLT, e a do doméstico. Ora, sujeito a jornada não superior a vinte e cinco horas semanais, poderia aquele primeiro, perfeitamente, laborar para determinado empregador apenas alguns dias por semana. Conseqüentemente, factível lhe seria se ativar para outro tomador nas demais ocasiões semanais. Tal fato, definitivamente, não descaracterizaria os dois vínculos de emprego nos quais estaria inserido o obreiro. Incoerente é se considerar, assim, que para o doméstico tido como diarista, o faria. Isso porque, plenamente idênticas seriam as condições de não-eventualidade do labor efetuado.

Melhor elucidando tal questão, e resumindo o entendimento ao qual também nos filiamos, assevera de forma preclara Sergio Pinto Martins que "o fato de a diarista prestar serviços uma vez por semana não quer dizer que inexista relação de emprego. (...) O importante, no caso, é a faxineira ter a obrigação de comparecer sempre em determinado dia da semana, v.g., segunda-feira, a partir das oito horas da manhã até as 16h, ficando evidenciada a subordinação pela existência de imposição patronal quanto ao dia e horário de trabalho". ${ }^{10}$

\subsection{Do caráter não-lucrativo da prestação de serviços}

A natureza da atividade desempenhada pelo obreiro não é essencial para a definição de determinado labor como doméstico ou-não. Define-se tal qualificação, na verdade, em razão da existência ou-não de lucratividade na prestação de serviços.

Ressalte-se, nesse mister, que em toda e qualquer atividade de cunho oneroso, a natureza econômica do labor é latente. Uma das partes, no mínimo, objetiva sempre lucro em tal relação. Refere-se o conceito legal de não-lucratividade do trabalho, todavia, estritamente à figura do empregador. Configura-se emprego doméstico, então, quando a finalidade direta do empregador, no pacto laboral em comento, não seja a de obter aumento patrimonial ou garantir a subsistência. "Não é que o trabalho doméstico

${ }^{10}$ MARTINS, Sergio Pinto. Direito do trabalho. 17. ed. São Paulo: Atlas, 2003. p. 150 
não possua significação econômica, e sim que não se destina ao mercado mas ao consumo doméstico". ${ }^{11}$

Assim é que, para que seja caracterizado como de natureza doméstica, o trabalho deve ser realizado fora de qualquer contexto econômico, ou seja, sem ligação com qualquer empreendimento de que participe o empregador, e do qual obtenha ele proveito econômico. Se a sua finalidade não for direcionada unicamente às necessidades familiares em âmbito residencial e à manutenção do lar, o trabalho não será doméstico.

\subsection{Do labor em âmbito residencial}

Para que se configure relação de emprego doméstica, indispensável é que o labor seja desempenhado em benefício de pessoa física, ou a um núcleo familiar. Em outras palavras, descaracterizado estaria o liame empregatício caso o trabalho fosse prestado para pessoa jurídica.

Insta salientar que a expressão "em âmbito residencial", empregada pela Lei n. 5.859/72, é pacificamente interpretada em sentido amplo pela doutrina e pela jurisprudência. Compreende, portanto, além da residência propriamente dita e de suas dependências, também todo espaço em que seja desempenhado labor direcionado estritamente, essencialmente aos membros da família. Consoante perfeitamente elucida Carlos Moreira de Luca, configura-se labor doméstico quando desempenhado "onde quer que se desenvolva a vida familiar, na residência, em casa de veraneio, sítio de recreio, ou seja, no círculo de vida familiar, desde que a prestação não tenha o intuito de proporcionar lucros ou rendimentos pecuniários". ${ }^{12}$

Contextualizando concretamente tal requisito, insta esclarecer que não se limita o conceito de empregado doméstico às figuras das faxineiras, babás, ou cozinheiras, incorporando, outrossim, todo e qualquer obreiro que se ative ou na própria residência da família, ou em seus desdobramentos. Assim é que incluídos estão, igualmente, na definição de domésticos, o motorista particular, o jardineiro, o caseiro de imóvel de veraneio, dentre outros.

\footnotetext{
11 MAGANO, Octavio Bueno. Manual de direito do trabalho. 2. ed. São Paulo: Ltr, 1992. v. 2, p. 101.

12 LUCA, Carlos Alberto de. Contrato de emprego doméstico. Revista de Direito do Trabalho, São Paulo, a. 7, n. 36, p. 29, mar./abr. 1982 apud FERRAZ, Fernando Basto. Empregados domésticos, p. 29.
} 
4. Evolução legislativa da proteção dispensada ao empregado doméstico no Brasil

As primeiras disposições legais destinadas a regular o trabalho em âmbito doméstico remontam ao ano de 1830, e eram consubstanciadas em Ordenações do Reino de Portugal, que regulavam o contrato escrito sobre prestação de serviços efetuados por estrangeiros ou brasileiros dentro ou fora do Império. "Esta lei de caráter genérico compreendia também as relações de emprego doméstico". ${ }^{13}$

Em 1886, foi editado o Código de Posturas do Município de São Paulo, o qual definia em seu artigo 263, como criado de servir, dentre outras, "toda pessoa de condição livre que, mediante salário convencionado, tiver ou quiser ter ocupação de (...) qualquer serviço doméstico". Assegurava a tais criados o direito a aviso prévio de cinco dias, na rescisão contratual de iniciativa do empregador, bem como a obrigação de registro na Secretaria de Polícia, e a de conceder aviso prévio de oito dias, quando de sua iniciativa para a extinção do pacto laboral. "Dispunha o Código ainda que é motivo de justa causa rescisória o fato de o empregado ficar impedido para o trabalho por doença ou para o caso de sair, deliberadamente, mormente à noite". ${ }^{14}$

Já em 1890, momento anterior portanto à vigência da primeira Constituição da República brasileira, foi promulgado, pelo Governo do Estado do Piauí, o Decreto n. 23, de 11 de abril de 1890, disciplinando o que denominava de contratos de locação de serviço doméstico celebrados no âmbito daquele Estado. O regulamento daquele Decreto, promulgado no mesmo ano, era composto de 61 artigos, e fixava diversos direitos e obrigações às partes, tais como a de obrigatoriedade de assinatura de carteira de trabalho, e as sanções decorrentes da extinção contratual.

Em âmbito puramente nacional, as primeiras regras originariamente brasileiras, que vieram em substituição às ordenações do Reino de Portugal, foram trazidas pelo Código Civil de 1916, promulgado por meio da Lei n. 3.071, de $1^{\circ}$ de janeiro de 1916, o qual em seus arts. 1.216 a 1.236, disciplinava os contratos de trabalho doméstico como uma relação de locação de serviços.

Dentre as previsões ali insertas, destacamos a que previa possibilidade de assinatura do contrato a rogo, quando uma das partes não soubesse ler e escrever (art. 1.217); a que limitava a duração do contrato ao prazo máximo de quatro anos (art. 1.229); a que previa a necessidade de concessão de aviso prévio de oito, quatro ou um dia, quando

\footnotetext{
13 NORMANDO, Claudia Cavalcante. Trabalho doméstico: valores jurídicos e dignidade humana. 1. ed. Porto Alegre: Sergio Antonio Fabris Editor, 2005. p. 68.

14 Id. Ibid., p. 68
} 
da extinção da contratualidade, dependendo da duração do pacto (art. 1.221); e a que assegurava ao locador dispensado sem justa causa o direito a indenização equivalente à metade da remuneração devida até o término do contrato (art. 1.228).

Aos 27 de fevereiro de 1941, iniciou-se a vigência do Decreto-lei n. 3.078, destinado a disciplinar, especificamente, a locação de empregados em serviços domésticos. Definia tal Decreto, em seu artigo primeiro, os empregados domésticos como "aqueles que, de qualquer profissão ou mister, mediante remuneração, prestem serviços em residências particulares ou a beneficio destas".

Consoante bem observa Fernando Bastos Ferraz, em sua obra "Empregados Domésticos", "esta conceituação de empregado doméstico merece crítica por não precisar a quem deva ser prestado o serviço, além de não estabelecer a condição de destinar-se ele à economia de consumo da família". ${ }^{15}$ De fato, tornaria possível, a disposição legal em tela, enquadrar-se como doméstico aquele trabalhador que, a despeito de realizar tarefas no âmbito da residência de seu empregador, não o faz em atividades inerentes ao núcleo familiar, como no caso clássico do empregado que colabora com seu empregador na atividade de fabricação de doces caseiros para venda ao público geral.

A despeito da narrada imprecisão conceitual, trazia o Decreto ora em comento uma série de direitos que demonstravam certa evolução na proteção do obreiro doméstico. Assim é que assegurava aviso prévio de oito dias para a resolução de contratos cuja vigência tivesse ultrapassado o período de seis meses, sob pena de pagamento de indenização correspondente a oito dias de salários (art. $3^{\circ}, \S 1^{\circ}$ ); a obrigatoriedade de anotação pelo empregador, do contrato em Carteira de Trabalho do empregado (art. $4^{\circ}$ ); os deveres contratuais do empregado e empregador (arts. $6^{\circ}$ e $7^{\circ}$ ); e o direito à indenização do empregado quando da rescisão injustificada do contrato por iniciativa do empregador (art. 10). No plano previdenciário, assegurava em seu art. 16 a realização de estudos, por parte do Ministério do Trabalho, Indústria e Comércio, destinados "ao estabelecimento de um regime de previdência social para os empregados domésticos".

Posteriormente, aprovada a Consolidação das Leis do Trabalho, a qual expressamente exclui, em seu art. $7^{\circ}$, “a”, os domésticos de seu campo de aplicação, passou a parcela majoritária da doutrina a considerar revogado o Decreto-lei n. 3.078/41. Isso com suporte no fato de que a CLT teria se transformado no único diploma destinado à proteção do trabalhador, revogando todas as demais normas atinentes a tal finalidade, fossem gerais ou específicas, desde que de âmbito nacional e vigência indeterminada. Essa foi a exegese

\footnotetext{
${ }^{15}$ FERRAZ, Fernando Bastos. Empregados domésticos. 1. ed. São Paulo: Ltr, 2003. p. 39
} 
feita, dentre outros, por Arnaldo Sussekind ${ }^{16}$ sobre o artigo $1^{\circ}$, parágrafo único, do Decreto n. 5. 452, de $1^{\circ}$ de maio de 1943, que aprovou a Consolidação das Leis do Trabalho. Em sentido contrário, embora minoritariamente, defendiam Amauri Mascaro do Nascimento ${ }^{17}$ e Mozart Victor Russomano ${ }^{18}$ que por se tratar de lei especial, destinada a regrar campo expressamente excluído pela CLT, permanecia em vigência o supramencionado Decretolei.

Aos 23-04-1956, promulgada a Lei n. 2.757, foram expressamente excluídos da categoria de domésticos, e portanto inseridos no regime celetista, os empregados porteiros, zeladores, faxineiros e serventes de prédios e apartamentos residenciais a serviço da administração do condomínio, e não dos condôminos em particular.

Com relação aos demais domésticos, permaneceu em discussão a aplicabilidade do referido Decreto-lei n. 3.078/41, até a promulgação da Lei n. 5.859, de 11 de dezembro de 1972, que em conjunto com seu Decreto n. 71.885, de 9 de março de 1973, que a regulamenta, e o artigo $7^{\circ}$, parágrafo único da Constituição Federal, posteriormente promulgada aos 05-10-88, são pacificamente vistas como as normas atualmente destinadas a regrar as relações de emprego doméstico. Dessa forma, faz-se necessária a análise de seu conteúdo, o que se passa a realizar em seguida.

5. Atual regime jurídico assegurado ao empregado doméstico

Conforme já exposto, o atual regime de direitos assegurados aos empregados domésticos se encontra previsto, principalmente, na Lei n. 5.859/72, no Decreto n. $71.885 / 73$, e no parágrafo único do artigo $7^{\circ}$ da Constituição da República Federativa do Brasil.

A Consolidação das Leis do Trabalho, nos termos do seu art. $7^{\circ}$, “a”, exclui os empregados domésticos do âmbito de aplicação de seus preceitos. Por tal motivo, é dominante o entendimento de que, ressalvadas expressas exceções legais, nenhum dos direitos ali previstos é estendido àquela classe de obreiros.

Inicialmente, assegurava a Lein. 5.859/72 apenas três direitos aos empregados domésticos, quais sejam os de férias anuais remuneradas de vinte dias úteis, o de anotação da contratualidade em CTPS, e o de inscrição como segurado obrigatório na Previdência

\footnotetext{
16 SUSSEKIND, Arnaldo. Comentários à CLT e à legislação complementar. 2. ed. Rio de Janeiro: Freitas Bastos, 1964. p. 23, apud FERRAZ, Fernando Basto. Empregados domésticos, p. 42.

17 NASCIMENTO, Amauri Mascaro. Compêndio de direito do trabalho. São Paulo: Ltr, 1972. p. 67, apud FERRAZ, Fernando Basto. Empregados domésticos, p.41.

18 RUSSOMANO, Mozart Victor. Comentários à CLT. Rio de Janeiro: Forense, 1982. p. 34.
} 
Social. Tal legislação, aliada ao já mencionado conteúdo da norma consolidada, bem como ao teor do art. 5", "a", da Lei n. 605/1949, que lhes vedava a concessão de descanso semanal remunerado, compunha todo o arcabouço legal direcionado aos domésticos.

Melhor detalhando a matéria, o Decreto n. 71.885/73, que aprovou o regulamento da supramencionada lei, dispôs ainda exceção àquele preceito celetista excludente, no sentido de ser aplicável sobre as relações de emprego doméstico o teor do capítulo da Consolidação das Leis do Trabalho referente ao direito de férias.

Com base em tal dispositivo, passou-se a entender, mesmo que de forma não uníssona, ter sido assegurado a tais empregados o direito a férias proporcionais, quando da rescisão da contratualidade antes de completo o período aquisitivo do direito a tal repouso em sua integralidade, bem como o direito à remuneração dobrada das férias concedidas fora do período concessivo correspondente. Apesar de majoritariamente aceito, discutido, todavia, ainda na atualidade, é o cabimento de tais garantias.

Posteriormente, a legislação atinente ao Vale-Transporte veio também a contemplar o empregado doméstico com tal parcela. Salienta-se, contudo, que o referido direito não foi concedido na legislação que o implementou originariamente, consubstanciada nas Leis ns. 7.418/85 e 7.619/87, mas apenas quando da expedição do Decreto n. 95.247, de 17-11-87 (art. $1^{\circ}$, II), destinado a regulamentar as aludidas leis.

A Constituição da República Federativa do Brasil, promulgada em 05-1088, trouxe certa extensão ao rol de parcelas asseguradas aos empregados domésticos. Assim é que o parágrafo único de seu art $7^{\circ}$ passou a assegurar a tal classe obreira, além dos títulos acima mencionados, também os direitos ao salário mínimo, à irredutibilidade salarial, ao décimo terceiro salário, ao repouso semanal remunerado, preferencialmente aos domingos, ao gozo de férias remuneradas anuais, com acréscimo remuneratório de pelo menos um terço do salário normal, licença à gestante, sem prejuízo de emprego e salário, com duração de cento e vinte dias, licença-paternidade, nos termos legalmente assegurados, aviso prévio proporcional ao tempo de serviço, de no mínimo trinta dias, e aposentadoria, além da integração à previdência social.

A partir do mês de março de 2000, por intermédio da Medida Provisória n. 1.986/1999, subseqüentes revisões, e final conversão na Lei n. 10.208/2001, passou a ser optativa a inclusão, pelos empregadores domésticos, de seus empregados no Fundo de Garantia por Tempo de Serviço. Conseqüentemente, além do direito aos depósitos mensais, assegurado estaria ao doméstico cujo patrão optasse por tal regime, o direito à indenização rescisória de $40 \%$ sobre o FGTS recolhido ao longo de toda a contratualidade, bem como ao benefício do seguro desemprego. Esse, contudo, seria concedido em montante menor 
que aquele assegurado aos empregados comuns, vez que limitado a no máximo três parcelas, no valor equivalente a um salário mínimo.

Nota-se, portanto, que a despeito de ter se operado certo crescimento, ao longo dos tempos, do leque de direitos assegurados aos empregados domésticos, ainda assim permaneceram tais trabalhadores excluídos do campo de aplicação de importantíssimas normas protetivas. Tal exclusão, consigne-se, resulta em patente discriminação de tratamento legal dispensado a essa classe obreira, em comparação àquele conferido aos demais empregados comuns.

Assim é que, muito embora esteja o empregado doméstico, em seu labor, sujeito aos mesmos riscos de quedar acometido por acidentes, aos quais está submetido qualquer outro empregado, não faria jus, consoante entendimento atual majoritário, a indenização acidentária. Da mesma forma, mesmo se em contato com agentes insalubres ou perigosos em seu labor, não lhe seria assegurada a percepção do correspondente adicional de remuneração.

Igualmente, apesar de estarem sujeitos a desgaste físico, assim como está todo trabalhador, não lhe são assegurados o respeito a qualquer limite de jornada, tampouco a conseqüente percepção de horas extras, quando extrapolados os limites de oito horas diárias e quarenta e quatro semanais, e sequer o adicional noturno, quando labora em hora noturna. Em resumo, desconsiderada, no tocante aos empregados domésticos, é toda a proteção legislativa dispensada aos demais trabalhadores, como medida de saúde, higiene e segurança do trabalho.

Consoante perfeitamente sintetiza Maurício Godinho Delgado, “aduz a posição hermenêutica hoje dominante que no instante em que a carta de 1988 pretendeu se referir e englobar em suas normas a categoria doméstica, fê-lo expressa e topicamente (parágrafo único do art. $7^{\circ}, \mathrm{CF} / 88$ ). Assim, descaberia produzir-se interpretação extensiva onde a Constituição conferiu tratamento restrito e excetivo". ${ }^{19}$

De fato, a superficial análise da jurisprudência pátria já permite diagnosticar o fato de que impera o entendimento no sentido de que o rol do art. $7^{\circ}$, parágrafo único da Lei Maior seria taxativo, não comportando dilações. É o que se sustenta, à guisa de exemplificação, no julgado abaixo referido, cuja ementa transcreve-se abaixo, verbis:

AGRAVO DE INSTRUMENTO. EMPREGADO
DOMÉSTICO. HORAS EXTRAS. 1. O art. $7^{\circ}$ da
$\begin{aligned} & \text { Constituição Federal, em seu parágrafo único, não } \\ & \text { oferece aos trabalhadores domésticos o resguardo dos }\end{aligned}$

${ }^{19}$ DELGADO, Maurício Godinho. Curso de direito do trabalho. 4. ed. São Paulo: LTr, 2005. p. 379. 
incisos XIII e XVI, assim não lhes assegurando o direito à jornada limitada e às horas extras. Tais títulos também não encontram previsão na legislação ordinária (Lei n. 5.859/72). 2. A despeito das condições atípicas em que se dá o seu ofício, com a natural dificuldade de controle e de atendimento aos direitos normalmente assegurados aos trabalhadores urbanos, não há dúvidas de que a legislação é tímida em relação aos empregados domésticos, renegandolhes determinadas garantias necessárias à preservação de sua dignidade profissional (CF, art. $1^{\circ}$, III). 3. Esta certeza, no entanto, não autoriza, no plano judicial, a superação das fronteiras estabelecidas pelas normas vigentes, de forma a se compelir o empregador ao adimplemento de obrigação que o ordenamento jurídico não lhe impõe. É impossível o deferimento de horas extras ao empregado doméstico. Agravo de instrumento conhecido e desprovido. (TST, AIRR 810/2001-002-17-00. PUBLICAÇÃO: DJ - 23/06/2006. Relator: Ministro Alberto Bresciani).

Recentemente, por intermédio do Projeto de Conversão da Medida Provisória n. 284/2006 em Lei, foi levado à tramitação um conjunto de emendas propostas pelo Senado Federal, sobre tal norma, que buscavam assegurar uma diversidade de direitos até então excluídos à classe doméstica, dentre os quais o da obrigatoriedade de inscrição no FGTS; o de garantia provisória de emprego à gestante; o de férias remuneradas com trinta dias de duração; e o de vedação de descontos sobre o salário. Tal projeto redundou na promulgação da Lei n. 11.324, de 19-07-06, que infelizmente, vetando os demais dispositivos, limitou-se a reconhecer aos domésticos à intangibilidade salarial, vedando-se a possibilidade de descontos, salvo os expressamente permitidos em lei, o direito a férias integrais de trinta dias, e também a garantia de emprego à gestante.

Independentemente da finalidade que moveu o órgão legislativo à tomada de tal iniciativa, o que realmente se extrai de tal evento legislativo é a conclusão de que plenamente possível é a equiparação do regime jurídico dos domésticos com o dos demais obreiros. Tanto o referido é verdade que, como visto, restou recentemente aprovada a majoração, ainda que parcial, de direitos. A distinção de tratamento apenas se justifica caso realmente exista fundamento fático ou jurídico apto a sustentar o discrímen. Ao nosso ver, não é o que ocorre no contexto em debate.

Consignamos, ainda, que mesmo com a edição da referida lei, ainda assim persiste a discriminação negativa dispensada ao doméstico, vez que diversos direitos ainda não lhe são assegurados. Apesar de bem-vinda, tímida se mostra a reforma implementada. 
A oportunidade poderia ter sido aproveitada para se promover a plena equiparação de direitos.

Assim sendo, entendemos que tal posicionamento majoritário, acima esposado, não merece prosperar quando efetuada uma exegese sistemática do conteúdo da Constituição, levando-se em conta os princípios e valores que a permeiam. Nesse sentido, parece-nos mais adequado, justo e equânime sustentar que o rol de direitos assegurados a tal classe obreira, estampado na Carta Magna, é meramente exemplificativo, sendo cabível sua extensão, a qual ensejaria a plena equiparação do regime jurídico que lhes é assegurado àquele previsto aos demais trabalhadores celetistas.

É tal exegese que se pretende por ora construir. Entretanto, antes de adentrarmos em tal estudo especificamente considerado, insta trazer à baila, ainda, o teor de normas internacionais, destinadas à proteção de direitos humanos, por meio das quais tornase ainda notório o fato de que a comunidade internacional não tolera qualquer discriminação infundada entre trabalhadores submetidos a condições isonômicas de trabalho. A ordem jurídica pátria, aderindo a tais instrumentos, comprometeu-se então a igualmente nãofazê-lo, fato esse que reforça ainda mais a argumentação referente à necessidade premente de mudança na exegese dada ao mencionado dispositivo constitucional.

6. Instrumentos internacionais de proteção aos direitos humanos com repercussão no trabalho doméstico

Em âmbito supranacional, a proteção dos direitos humanos é implementada principalmente por meio da celebração de instrumentos internacionais.

Com relação à proteção dos trabalhadores, merecem destaque a Declaração Universal dos Direitos Humanos, de 1948, bem como os Pactos sobre Direitos Civis e Políticos e o sobre Direitos Econômicos, Sociais e Culturais, celebrados em 1966, além da Convenção Americana, de 1969.

O primeiro dos documentos internacionais ganha importância para o estudo ora realizado, uma vez que contemplou os ideais de igualdade, liberdade e fraternidade. Esse último princípio vem afirmado nos arts. XXII a XXVI, "compreendendo o direito dos mais necessitados à seguridade social, ao trabalho e à proteção contra o desemprego, incluindo como direitos inerentes ao contrato de trabalho: a remuneração igual por 
trabalho igual; o salário mínimo; o repouso e o lazer; a limitação da jornada de trabalho; as férias remuneradas". ${ }^{20}$

Consigne-se, ainda, que tal declaração apresenta como características marcantes "sua amplitude, posto que compreende um conjunto de regras protetoras à integridade física, moral e intelectual do homem; e pela universalidade, pois aplicável a todo ser humano". ${ }^{21}$

Os Pactos sobre Direitos Civis e Políticos, e sobre Direitos Econômicos, Sociais e Culturais, de 1966, por sua vez, manifestam-se relevantes, na medida em que o primeiro, ao longo de seus 47 artigos, assegura direitos fundamentais, dentre os quais o da igualdade, e o segundo, por sua vez, elenca uma série de direitos destinados à proteção dos econômica e socialmente hipossuficientes, tais como os de trabalho e justa remuneração, e o de descanso e lazer, inclusive com limitação razoável de horas de trabalho, férias e feriados remunerados. Ressalta-se, ainda, que os preâmbulos de ambos os pactos estabelecem que os direitos humanos ali fixados são estruturados na dignidade da pessoa humana, valor que representa fundamento da liberdade, justiça e paz.

Já a Convenção Americana sobre Direitos Humanos possui indiscutível importância vez que prevê o princípio da supremacia dos direitos humanos mais vantajosos, o qual se resume, nas palavras de Cláudia Cavalcante Normando, “à aplicação do dispositivo legal mais benéfico ao homem, quando da vigência de vários sistemas normativos (nacional e internacional), conflituosos entre si", ${ }^{22}$

O Protocolo de São Salvador, de 1988, adicional a tal Convenção, estabelece em seu art. $7^{\circ}$ o direito ao trabalho livre, determinando aos Estados signatários que suas legislações deveriam assegurar, a todos os trabalhadores, indiscriminadamente, o direito de ter estabilidade no emprego, com garantia de readmissão e indenização, de ser respeitada limitação razoável de horas de trabalho, e a vedação do trabalho noturno, insalubre ou perigoso aos menores de 18 anos. Já o art. $9^{\circ}$ reafirma o direito de todos os trabalhadores à Previdência Social, inclusive com o recebimento de subsídio e pensão, em caso de acidente de trabalho ou doença profissional. Foi tal protocolo ratificado pelo Brasil, por meio do Decreto legislativo n. 56/1995.

Por fim, vale ainda destacar a Convenção n. 103 da OIT, que em seu art. $1^{\circ}$ versa sobre a proteção à maternidade, no sentido de concessão de estabilidade, aplicável

\footnotetext{
${ }^{20}$ NORMANDO, Claudia Cavalcante. Trabalho doméstico: valores jurídicos e dignidade humana. 1. ed. Porto Alegre: Sergio Antonio Fabris Editor, 2005. p. 106.

21 Id. Ibid., p. 105.

22 Id. Ibid., p. 109.
} 
"às mulheres empregadas em empresas industriais e agrícolas, inclusive às mulheres assalariadas que trabalham em domicílio", além da Convenção n. 132, ratificada pelo Brasil, por meio do Decreto n. 3.197, de 05-10-1999, que assegura duração de férias idêntica a todos os trabalhadores (inclusive aos domésticos, portanto), nunca inferior a três semanas de trabalho, por um ano de serviço, fazendo exceção unicamente aos marítimos.

Muito embora, como demonstrado, sejam tais instrumentos internacionais aplicáveis indistintamente a todos os trabalhadores, e tragam em seus preceitos conteúdo claramente mais favorável aos domésticos que aquele estabelecido no regime jurídico ora vigente, insiste a jurisprudência e a doutrina majoritárias que, ainda assim, em âmbito de emprego doméstico, não são aplicáveis tais dispositivos de forma plena, sob o fundamento de que tal relação apresenta peculiaridades que justificam o tratamento diferenciado. Insta analisar, portanto, tais especificidades, e se realmente são pertinentes para justificar o tratamento diferenciado.

7. Dos principais fundamentos destinados a justificar a restrição de direitos assegurados aos domésticos

Consoante melhor se detalhará mais adiante, para que seja reputado válido, um determinado tratamento discriminatório deve ser acompanhado de correlação lógica com as causas que o fundamentam.

Buscar-se-á, nesse momento, apontar exatamente quais as possíveis causas, tanto de ordem histórico-social, como fático-jurídica, que justificam o vislumbrar do parágrafo único do art. $7^{\circ}$ da Constituição Federal como um rol restrito de direitos dos empregados domésticos.

\subsection{Dos fundamentos fático-jurídicos}

Questões atinentes à natureza do labor doméstico, bem como ao modo e local em que esse é desempenhado, costumam ser apontadas como justificadoras do tratamento diferenciado dispensado ao obreiro inserido nesse tipo de atividade.

De fato, muitos justificam a exclusão de determinados direitos sociais do patrimônio dos domésticos sob o fundamento de que a essência de tal relação empregatícia não é lucrativa. Dessa forma, por serem considerados como próprios do trabalho inserido em atividade econômica, é que alguns títulos juslaborais como estabilidades, controle de jornada, dentre outros, não seriam assegurados àqueles empregados. 
Tal justificativa foi inclusive adotada pela assembléia constituinte, encarregada da elaboração do texto ora em vigor. Tanto o referido é verdade que esse fundamento foi utilizado para a rejeição de pedidos de emendas ao projeto de Constituição.

À guisa de ilustração, mostra-se válido fazer referência ao pedido de emenda supressiva n. 01372, apresentado aos 09-06-87, de autoria de Abigail Feitosa, representante do Partido da Mobilização Democrática Brasileira, que recomendava a exclusão, do texto do projeto, exatamente do dispositivo equivalente ao atual parágrafo único do art. $7^{\circ} \mathrm{da}$ Lei Maior. Sobre tal pleito, emitiu-se o parecer abaixo ilustrado, ipsis litteris:
A presença de artigo específico sobre empregados domésticos objetiva explicitar a diferenciação entre eles e os demais trabalhadores que decorre da natureza específica do trabalho que executam. O empregado doméstico presta serviços pessoais no lar do empregador, que não obtém lucro deles. Em conseqüência, não fazem jus à totalidade dos direitos do trabalhador.

Seguindo o mesmo raciocínio, sobre outro pleito de emenda supressiva, registrado sob o n. 00919, apresentado aos 02-07-1987, promovido por Darcy Pozza, membro do PDS do Rio Grande do Sul, proferiu-se parecer no sentido de que "todos os direitos do trabalhador que não se relacionem com a prestação de serviço a empregador que exerça atividade econômica, devem ser estendidos ao empregado doméstico".

Todavia, discutível é o cabimento de tal argumentação. Isso porque, apenas se analisada sob o prisma do empregador é que a atividade doméstica não se manifesta lucrativa. Ao empregado, o é. Por meio do trabalho doméstico é que esse obtém meios de sustento próprio, o de seus familiares, assegura sua sobrevivência e dignidade enquanto ser humano. Não se trata de labor voluntário, ou a título gratuito, mas sim oneroso, no qual o empregado vende sua energia laboral. É, portanto, lucrativo nesse aspecto.

Ademais, se também analisada a questão sob o enfoque do empregador, relativa é a ausência de lucro na atividade em comento. Isso porque, mesmo que de forma indireta, tal indivíduo obtém vantagens em razão do trabalho do empregado doméstico. Livre das tarefas domésticas, o empregador encontra mais tempo, e mais disposição para o desempenho de seus encargos profissionais. Dessa forma, maior pode vir a ser sua produtividade, o que conseqüentemente, dependendo da função que desempenha, torna possível um acréscimo em seus rendimentos. Indiscutível, portanto, que por via reflexa, o labor doméstico é apto a acarretar proveito financeiro ao empregador. 
Outra justificativa comumente utilizada refere-se ao fato de o trabalho ser realizado em âmbito doméstico, no núcleo de residência de uma familiar, protegida pelo manto da garantia à intimidade, de modo que a fiscalização do cumprimento de certas obrigações trabalhistas, tais como a de controle de jornada, ou o respeito a certa estabilidade assegurada, seriam inexeqüíveis.

Ao nosso ver, guardado o devido respeito aos defensores dessa idéia, impertinente se apresenta, também, tal entendimento. Isso porque, primeiramente, parte do pressuposto de que tais direitos não seriam observados, de maneira que necessária seria a fiscalização de seu cumprimento, ou a eventual comprovação de seu desrespeito em âmbito jurisdicional, quando do ajuizamento de demandas perante a Justiça do Trabalho.

Ora, a preocupação primária do operador do direito deve ser a de assegurar os direitos cabíveis a cada indivíduo, de acordo com a condição específica em que se inserem. A operacionalização desse arcabouço protetivo, sua fiscalização e controle, são questões secundárias, e de muito mais simples implementação. Insta consignar, nesse diapasão, ainda, que também o âmbito empresarial merece ter sua esfera de privacidade respeitada. Enquanto pessoas jurídicas de direito privado, as indústrias, fábricas ou sedes empresariais não são ambientes de franco acesso ao público, e mesmo assim, viável é a fiscalização trabalhista nesses locais.

Como corolário lógico, e tendo-se em vista ainda que, assim como qualquer outra garantia fundamental, a da inviolabilidade do domicílio também não é absoluta, merecendo ponderação com a necessidade de respeito da dignidade do empregado doméstico, plenamente plausível seria se imaginar a realização de certa fiscalização trabalhista no âmbito residencial, desde que, por óbvio, observados padrões de razoabilidade, ou seja, sem invadir o núcleo mínimo de intimidade assegurado aos moradores da residência.

Por fim, outro argumento sustentado como inviabilizador da equiparação de regimes jurídicos entre empregados comuns e o doméstico seria o de que a ampliação do rol de direitos dessa classe poderia acarretar acréscimo nos índices de emprego informal, decorrente do desinteresse, dos empregadores, de sustentar um contrato demasiadamente oneroso de emprego doméstico.

Certamente, não pode tal argumento sustentar um discrímen como o ora em apreciação. Isso porque, aspectos econômicos, de modo algum, podem ser utilizados para justificar o descumprimento de normas de ordem pública, assecuratórias de condições mínimas de dignidade ao ser humano. Nesse aspecto, vale mencionar que inexiste na ordem jurídica pátria dispositivo algum que obrigue todo cidadão a celebrar contrato de emprego doméstico. Dessa forma, aqueles que não reúnem condições financeiras de fazê- 
lo, não estão compelidos a assim atuar. De certo, seguida tal linha de análise, mais acirrada ainda que atualmente quedaria a concorrência por uma colocação no mercado de trabalho. Todavia, o uso de tal fato como móvel à obtenção da energia laboral alheia, mediante contraprestação injusta, representa patente, torpe e abusiva exploração de mão-de-obra, prática inadmissível há longa data, tanto em âmbito interno como internacional.

\subsection{Da influência dos fatores histórico-sociais}

As já delineadas raízes históricas do trabalho doméstico em muito influenciam na forma em que tal atividade, mormente no Brasil, é ainda atualmente encarada. Como bem define Fernando Bastos Ferraz, o empregado doméstico atualmente é uma resultante do trabalho escravo da Antigüidade, com influências democráticas paternalísticas". ${ }^{23}$

E de fato, como visto, inicialmente o trabalho doméstico era desempenhado por escravos. Tratava-se de mão-de-obra escrava atuante dentro do núcleo familiar do proprietário. Esse contato próximo com os senhores, aliás, gerava neles certa sensibilização com as condições dos escravos domésticos, de modo que, dentro de padrões não tão elevados de respeito à dignidade humana, característicos em regime de escravidão, vinham os servos a gozar de certas regalias. Assim é que, esses domésticos recebiam, a título de regalo, e de certa forma como recompensa pelo labor efetuado, roupas usadas de seus donos, o direito de acompanhar o senhor em passeios, dentre outras supostas vantagens.

Mesmo depois de abolida a escravatura, persistiu tal estigma, vez que os escravos, sem perspectiva de trabalho livre, permaneciam nas fazendas, laborando para os antigos senhores, em troca de comida e local para dormir. Prestavam serviços, portanto, "na condição de trabalhadores livres do ponto de vista legal, mas aprisionados quanto aos aspectos social e econômico". ${ }^{24}$

Pois bem. Nota-se que tanto durante, e mesmo no período posterior à abolição da escravatura, os benefícios concedidos aos trabalhadores domésticos eram sempre encarados como favores, como prestações benevolentes concedidas pelos tomadores do serviço. E tal conceito persiste arraigado na cultura pátria.

Por tal motivo é que se torna tão árdua a tarefa de se justificar, perante os empregadores, a extensão de todo o rol de direitos elencados nos incisos do art. $7^{\circ}$ da Carta Magna aos empregados domésticos. Consideram aqueles que o simples fato de subsidiarem moradia, alimentação, e qualquer parcela remuneratória já seria suficiente

\footnotetext{
${ }^{23}$ FERRAZ, Fernando Bastos. Empregados domésticos. 1. ed. São Paulo: Ltr, 2003. p. 32.

${ }^{24}$ NORMANDO, Claudia Cavalcante. op. cit., p.49
} 
para atender a todas as necessidades do empregado. Afinal de contas, a relação, segundo o prisma geral dos empregadores, não seria essencialmente empregatícia, mas sim de amizade, de colaboração mútua.

Espelhando de forma direta a realidade dos fatos, e buscando demonstrar o quão falacioso é tal argumento utilizado pelo empregador, Fernando Basto Ferraz tece as seguintes considerações, abaixo transcritas in verbis:

Muitas donas de casa costumam driblar o pagamento de um salário justo ao final do mês, adotando a tese da amizade, fazendo a doméstica crer que faz parte da família. Ocorre, porém, que este parentesco cai por terra na hora da festinha da família, quando tem de ficar na cozinha, trabalhando ou no quarto, dormindo". 25

Em resumo, o costume de se desvalorizar o trabalho doméstico, de considerálo como indigno de plena valorização social, encontra-se historicamente arraigado na cultura brasileira. Tanto o referido é verdade, que tal influência é diagnosticada ainda na atualidade. Nas palavras de Eva Blay, "o país tem uma estrutura escravista, que se perpetua sutilmente na classe média... E quem paga isso são as domésticas" ${ }^{\text {26 }}$.

A essência do tratamento jurídico dispensado aos domésticos não encontra portanto forte sustentação fática, sequer jurídica. Aparenta, portanto, que sua raiz efetivamente é histórica, social, decorrente do modo em que o labor doméstico era originariamente realizado, e da tradição que de tal fato resultou. Ocorre que tal contexto, perante a ordem jurídica atual, demanda urgente superação, na medida em que díspare com todos os princípios consagrados em tratados internacionais, bem como com os objetivos e fundamentos de nosso Estado Democrático de Direito, estampados no corpo da Constituição.

Nesse contexto, torna-se necessário o delineamento de uma nova interpretação da ordem jurídica destinada a alterar o status ora presente, eliminando os preconceitos historicamente arraigados na sociedade.

25 FERRAZ, Fernando Bastos. Empregados domésticos. 1. ed. São Paulo: Ltr, 2003. p. 97.

${ }^{26}$ BLAY, Eva. Efeito doméstico. Revista Veja, 09/03/88, p. 32, apud FERRAZ, Fernando Bastos. Empregados domésticos. 1. ed. São Paulo: LTr, 2003. p. 32. 
8. Da possibilidade de reconhecimento dos direitos não assegurados aos empregados domésticos mediante interpretação sistemático-principiológica da Constituição Federal

Assim como acima delineado, a despeito de todo o relativo avanço legislativo alcançado ao longo da história, o empregado doméstico continua, ainda na atualidade, a receber tratamento distinto em comparação com o empregado comum, no tocante ao arcabouço juslaboral protetivo que lhe é assegurado.

Contudo, ao nosso ver, os motivos já expostos, que serviriam de suporte para tal distinção, não se manifestam suficientes para justificar tal situação discriminatória, mormente no presente contexto jurídico em que se encontra inserido nosso país, guiado por uma Constituição dita cidadã, que erigiu um Estado Democrático de Direito sobre fundamentos como os da dignidade da pessoa humana e valor social do trabalho, e que define como direito fundamental de todo indivíduo, o de receber tratamento isonômico com relação aos demais cidadãos.

Nesse diapasão, notória é a contradição existente entre o teor da Lei n. $5.859 / 72$, bem como da própria CLT, no tocante às regras diferenciadoras que trazem tais diplomas legais, e todo esse conteúdo principiológico constitucional. Igualmente, manifesta é a incoerência da leitura meramente gramatical da regra inserta no parágrafo único do art. $7^{\circ}$ da própria Lei Maior, quando apreciada a integralidade de tal diploma de forma sistemática.

Isso posto, faz-se imprescindível, com vistas a se recuperar a harmonia sistêmica da Constituição da República Federativa do Brasil, ultrapassarmos a mera leitura literal do supramencionado dispositivo constitucional, para adequá-lo aos termos, princípios e valores presentes e inspiradores de toda a Carta.

\subsection{Interpretação constitucional - considerações iniciais}

Interpretar é fixar o sentido e alcance de um determinado objeto. Na melhor definição de Celso Ribeiro Bastos, em um sentido mais estrito, é a "determinação de um significado de uma expressão lingüística quando existem duas referências a este significado em um caso concreto de comunicação". ${ }^{27}$

As normas jurídicas, em seu conteúdo, caracterizam-se pela abstração, por apresentarem teor impessoal e genérico, destinando-se a regular indefinidamente as

\footnotetext{
${ }^{27}$ BASTOS, Celso Ribeiro. Curso de direito constitucional. 20. ed. São Paulo: Saraiva, 1999. p. 61.
} 
relações sociais. Faz-se necessário, então, para a aplicação efetiva de tais preceitos, o emprego da hermenêutica jurídica. Essa consiste na ciência, no domínio teórico que tem por objeto o estudo sistemático das técnicas de interpretação de normas. Nesse mister, portanto, e nos termos da brilhante síntese de Luis Roberto Barroso, busca-se pela aplicação desse instrumental "revelar o conteúdo, o significado e o alcance de uma norma, tendo por finalidade fazê-la incidir em um caso concreto". ${ }^{28}$

As normas constitucionais, contudo, apresentam determinadas peculiaridades, traços característicos que geram a demanda de aplicação de instrumentos específicos em sua exegese. Melhor esclarecendo, traz a Constituição em seu bojo normas predominantemente principiológicas, de alto grau de abstração, e conseqüente reduzida densidade normativa, diferentes das demais normas insertas no ordenamento jurídico. Demanda-se então não apenas a subsunção do fato à regra, mas sim verdadeiro exercício de construção do sentido normativo, com base no espírito dos preceitos ${ }^{29}$.

Insta salientar, todavia, que a despeito de apresentar esses certos traços distintivos, a interpretação das normas constitucionais não se afasta das demais regras de hermenêutica incidentes em sede de Teoria Geral do Direito. O que se pretende expor é que, na realidade, ao lado das tradicionais regras interpretativas, a exegese constitucional demanda a utilização de técnicas específicas, destinadas a atender àquelas peculiaridades que qualificam o objeto a ser interpretado.

Assim é que, não basta para uma correta interpretação, a utilização dos métodos histórico, teleológico, gramatical, sistemático, dentre outros. Indiscutível é a importância de tais técnicas. Imperiosa, contudo, é a aplicação conjunta de outras medidas peculiares, denominadas de princípios instrumentais, tais como os da supremacia e unidade da constituição, além do da efetividade. Há que se atentar, ainda, ao fato de que a compreensão constitucional é condicionada pelos princípios contidos no bojo da Lex Fundamentalis.

Necessário se faz, portanto, antes de ingressarmos no cerne do processo exegético objeto do presente trabalho, melhor elucidar tais particularidades atinentes à interpretação constitucional, definindo com precisão quais instrumentos hermenêuticos e objetos normativos serão empregados nessa empreitada. É o que se passa a proceder em seguida.

\footnotetext{
${ }^{28}$ BARROSO, Luis Roberto. Interpretação e aplicação da Constituição. 6. ed. São Paulo: Saraiva, 2004. p. 103.

${ }^{29}$ Id. Ibid., p. 104.
} 
8.1.1. Métodos exegéticos tradicionais a serem empregados

Dentre os clássicos métodos interpretativos, enumerados por toda a clássica doutrina destinada a estudar o presente tema, encontram-se o gramatical, histórico, teleológico e sistemático.

Em linhas gerais, compreende-se a interpretação gramatical, também denominada literal, como "o exame de cada termo utilizado na norma, isolada ou sintaticamente, de acordo com as regras do vernáculo". ${ }^{30}$ Atenta tal método exclusivamente ao sentido que o texto da norma, que suas palavras exprime. Já o histórico consiste na "análise da norma partindo da premissa dos seus antecedentes históricos, verificando as circunstâncias fáticas e jurídicas que lhe antecederam, bem como o próprio processo legislativo correspondente". ${ }^{31}$

Ao longo do presente estudo, faremos uso mais incisivo dos métodos sistemático e teleológico. Aliás, resguardada a importância e relevância dos demais, insta citar que esses são considerados pela majoritária doutrina como os mais importantes métodos de interpretação, dentre os quatro ora em comento, vez que exprimem, de forma mais efetiva, o real conteúdo, a efetiva função sistêmica do preceito normativo. Dessa forma, cumpre-nos conceituar de forma mais detalhada tais modalidades de técnica interpretativa.

Entende-se por interpretação sistemática aquela em que a norma não é analisada isoladamente, mas sim em conjunto com todas as demais disposições existentes na ordem jurídica. Decorre sua utilização da unidade do ordenamento jurídico, do fato desse não ser composto por um aglomerado aleatório de preceitos legais, mas sim de um conjunto coerente e sistematizado. Pela interpretação sistemática, então, "o intérprete situa o dispositivo a ser interpretado dentro do contexto normativo geral e particular, estabelecendo as conexões internas que enlaçam as instituições e as normas jurídicas". ${ }^{32}$

Mostra-se extremamente importante o emprego do método exegético acima conceituado, para a finalidade pretendida na presente monografia, uma vez que o texto constitucional deve ser interpretado como um todo harmônico, ou seja, de modo que não se enxerguem choques entre suas regras, ou entre regras e princípios.

\footnotetext{
${ }^{30}$ GAUGLIANO, Pablo Stolze; PAMPLONA FILHO, Rodolfo. Novo curso de direito civil. 4. ed. São Paulo: Saraiva, 2003. v. 1, p .68.

31 Id. Ibid., p. 68.

32 BARROSO, Luis Roberto. Interpretação e aplicação da Constituição. 6. ed. São Paulo: Saraiva, 2004. p. 136.
} 
Já a técnica de interpretação teleológica atenta para o fato de que as normas devem ser aplicadas de forma a atender, a concretizar as finalidades às quais se destinam. Por tal método, então, procura-se "revelar o fim da norma, o valor ou bem jurídico visado pelo ordenamento com a edição de dado preceito". ${ }^{33}$

Vale ressaltar, no tocante a tal aspecto, que dado o dinamismo da ordem jurídica, a finalidade de determinada norma é passível de modificação, de evolução, sem que seja efetuada alteração em seu texto, donde inclusive se extrai a inegável importância do papel do intérprete na definição do real espírito de um preceito quando de sua aplicação. O método teleológico de compreensão das normas destina-se a fixar exatamente essa finalidade da norma, a denominada ratio legis. A circunstância histórica geradora da lei, a vontade do legislador, nem sempre se identifica com essa, sendo, como já visto, objeto de análise de outra técnica exegética, qual seja, a histórica.

Pois bem. Consoante já dantes exposto, para que se manifeste completa e correta, a interpretação constitucional deve conjugar os acima mencionados métodos clássicos de compreensão normativa, com técnicas outras destinadas a se moldar às peculiaridades de suas normas. Passemos, portanto, a verificar quais são esses traços específicos, e como operacionalizar sua exegese.

\subsubsection{Princípios instrumentais à interpretação constitucional}

A doutrina costuma denominar as técnicas específicas de interpretação constitucional como princípios instrumentais. São "premissas conceituais, metodológicas ou finalísticas que devem anteceder, no processo intelectual do intérprete, a solução concreta da questão posta". ${ }^{34}$

Para o exercício exegético a ser ora efetuado, far-se-á uso de três desses princípios instrumentais: os da supremacia e unidade da constituição, bem como o da efetividade. Analisemos, portanto, com maior apego, cada um deles.

\subsubsection{Princípio da supremacia da Constituição}

Em sede de sistema no qual vigora um texto constitucional rígido, qual seja aquele que prevê procedimento de reforma mais aparatoso que aquele estatuído

\footnotetext{
${ }^{33}$ BARROSO, Luis Roberto. Interpretação e aplicação da Constituição. 6. ed. São Paulo: Saraiva, 2004. p. 138.

${ }^{34}$ Id. Ibid., p. 370.
} 
para alteração das demais modalidades de lei, sob o ponto de vista jurídico, a principal característica da Constituição é a sua supremacia.

Com efeito, as normas constitucionais, nesse caso, ocupam patamar hierárquico superior àquele em que se encontram os demais preceitos legais, de modo que esses últimos não poderão ser considerados juridicamente válidos se incompatíveis com o conteúdo constitucional.

Nesse âmbito, a Constituição estatui, portanto, não-só o procedimento a ser necessariamente obedecido para a produção legislativa, como também delimita o conteúdo que tais normas infraconstitucionais apresentarão. Melhor esclarecendo, em razão da supremacia da constituição, uma norma que não se encontre em harmonia com o teor da Lex Fundamentalis, ou então que tenha sido confeccionada em inobservância às regras formais ali estatuídas, poderá quedar declarada inconstitucional pelas vias difusas ou concentradas de controle de constitucionalidade.

Igualmente, os dispositivos legais vigentes antes da promulgação da Carta Magna, quando incompatíveis com o teor dessa, perdem sua eficácia, são considerados não recepcionados pela nova ordem constitucional.

Tal princípio, portanto, impõe a prevalência das normas constitucionais na ordem jurídica. É nisso que se resume, em breves linhas, a idéia de supremacia da Constituição.

\subsubsection{Princípio da unidade da Constituição}

Consoante já delineado, a ordem jurídica é composta de forma sistêmica, uniforme, equilibrada e harmônica no tocante a seu conteúdo. Tal unidade, em face do acima estudado princípio da supremacia da Constituição, decorre exatamente do teor do texto constitucional.

A Constituição, portanto, como sistema do qual irradia toda a harmonia da ordem jurídica, deve necessariamente também se apresentar como um todo sistemático, unitário. É nesse ponto que se manifesta o princípio da unidade da Constituição, que portanto pode ser definido como "uma especificação da interpretação sistemática, e impõe ao intérprete o dever de harmonizar as tensões e contradições entre normas. Deverá fazê-lo guiado pela grande bússola da interpretação constitucional: os princípios fundamentais, gerais e setoriais inscritos ou decorrentes da Lei Maior". ${ }^{35}$

${ }^{35}$ BARROSO, Luis Roberto. Interpretação e aplicação da Constituição. 6. ed. São Paulo: Saraiva, 2004. p. 196. 
Constituições decorrentes do exercício do regime democrático, como a nossa atual, exatamente por representarem os anseios de diversos setores da sociedade, podem apresentar dispositivos aparentemente antagônicos. A grande finalidade da técnica interpretativa ora em comento, então, é exatamente a de buscar o equilíbrio entre os dispositivos, eliminando suas eventuais contradições.

Assim, "ao intérprete da Constituição só resta buscar a conciliação possível entre proposições aparentes antagônicas, cuidando, todavia, de jamais anular integralmente uma em favor da outra. (...) Cabe-lhe, portanto, o papel de harmonização ou otimização das normas, na medida em que se tem de produzir um equilíbrio, sem jamais negar por completo a eficácia de qualquer delas". ${ }^{36}$

Partindo do pressuposto de que a Constituição não contém palavras inúteis, e de que todas as normas nela insertas possuem um mínimo de efetividade, conclui a doutrina majoritária que a idéia de unidade constitucional decorre do fundamento básico de que inexiste antinomia real entre as normas constitucionais. Toda e qualquer discrepância representaria aparente conflito normativo, passível de solução por meio da aplicação dos corretos métodos interpretativos, ou buscando-se um equilíbrio das normas contraditórias em um mesmo caso, ou excluindo-se a aplicação de uma delas sobre dada situação.

Conclui-se, então, que o alcance da unidade da Constituição decorre da aplicação ou dos tradicionais métodos de integração do direito, ou de um exercício de ponderação sobre suas normas aparentemente conflitantes. Mais comumente, tal método é empregado quando do embate entre princípios, e consiste basicamente em se sopesar o campo de incidência de cada um deles, de modo que "cada princípio cederá espaço ao outro, através de restrições e compressões recíprocas que devem respeitar o princípio da proporcionalidade". ${ }^{37}$

Brilhantemente resumindo tal questão, Celso Ribeiro Bastos assevera que normas aparentemente em choque "podem harmonizar-se, desde que abdiquem da pretensão de serem interpretados de forma absoluta. Prevalecerão, afinal, apenas até o ponto em que deverão renunciar à sua pretensão normativa em favor de um princípio que lhe é antagônico ou divergente". ${ }^{38}$

\footnotetext{
${ }^{36}$ BARROSO, Luis Roberto. Interpretação e aplicação da Constituição. 6. ed. São Paulo: Saraiva, 2004. p.199200.

37 SARMENTO, Daniel. Direitos fundamentais e relações privadas. São Paulo: Malheiros, 2004. p. 85.

38 BASTOS, Celso Ribeiro. Curso de direito constitucional. 20. ed. São Paulo: Saraiva, 1999. p. 62.
} 
8.1.2.3. Princípio da efetividade

Como bem sintetiza Luis Roberto Barroso, a expressão efetividade traz a idéia de "realização do direito, atuação prática da norma, fazendo prevalecer no mundo dos fatos os valores e interesses por ela tutelados. Simboliza a efetividade, portanto, a aproximação, tão nítida quanto possível, entre o dever ser normativo e o ser da realidade social'. ${ }^{39}$

Cabe ao intérprete, portanto, quando da compreensão dos dispositivos constitucionais, direcioná-los de modo a obter a máxima eficácia possível dos preceitos fundamentais nela inseridos. Em outras palavras, sendo possível a adoção de diversas linhas interpretativas, deverá o exegeta adotar aquela que mais se aproximar da efetiva vontade constitucional, qual seja aquela espelhada por seu conteúdo principiológico.

Desenhadas as premissas procedimentais indispensáveis à realização de uma legítima interpretação constitucional, torna-se necessário verificar quais são os parâmetros materiais necessários para tal trabalho. Adianta-se que esses se resumem exatamente aos princípios emanados da Constituição. É o que se passa a elucidar.

\subsubsection{Dos princípios materiais como condicionantes da interpretação constitucional}

$\mathrm{Na}$ conceituação construída pelo renomado doutrinador Celso Antônio Bandeira de Mello, princípio é "mandamento nuclear de um sistema, verdadeiro alicerce dele, disposição fundamental que se irradia sobre diferentes normas compondo-lhes o espírito e servindo de critério para sua exata compreensão e inteligência, exatamente por definir a lógica e a racionalidade do sistema normativo, no que lhe confere a tônica e lhe dá sentido harmônico". ${ }^{40}$

Nesse exato diapasão adotado pela definição acima transcrita, pode-se dizer que os princípios constitucionais representam a síntese dos valores mais relevantes, as premissas básicas a regerem a ordem jurídica, e que se irradiam por todo o sistema.

Cumpre elucidar, ainda, que dentro da lógica pós-positivista largamente defendida na atualidade, a importância dos princípios em sede constitucional não mais se limita à mera instituição de conteúdo programático, ou ao impedimento de conduta legislativa contrária a seu teor. Reconhece-se, por hora, força normativa aos princípios.

\footnotetext{
39 BARROSO, Luis Roberto. Interpretação e aplicação da Constituição. 6. ed. São Paulo: Saraiva, 2004. p. 374.

${ }^{40}$ MELLO, Celso Antônio Bandeira de. Elementos de direito administrativo. São Paulo: Revista dos Tribunais, 1991. p. 230.
} 
Em outras palavras, superada está, nesse prisma teórico, a dicotomia entre normas e princípios. Esses, na verdade, passam a ser qualificados como espécies daquelas, e por sua vez distintos das regras, que também seriam espécies do gênero normas. ${ }^{41}$

Ambas essas subespécies de normas, contudo, em âmbito constitucional, ocupam o mesmo patamar hierárquico, até em face do supramencionado princípio da unidade da Constituição. O que as diferencia, na realidade, é o grau de abstração, mais latente nos princípios, bem como a finalidade a que cada uma se direciona.

Nessa esteira, desenham-se duas primordiais funções dos princípios: uma imediata, e outra mediata. A primeira, referente à aplicação do princípio, diretamente sobre uma relação jurídica, para regulá-la, mister para o qual é demandada densidade normativa suficiente. A segunda finalidade é, exatamente, a que se apresenta mais importante para a finalidade desse trabalho, qual seja a de funcionar como critério de interpretação e integração do texto constitucional. No tocante a tal função, apresentam os princípios força irradiante, de modo que o conteúdo constitucional por ele instituído se difunde e influencia na aplicação de todos os preceitos normativos infraconstitucionais.

De qualquer forma, reconhecida sua força normativa, não pode o teor dos princípios ser desconsiderado, independentemente da utilidade a que se destina.

Desse modo, deve o intérprete tomar os princípios constitucionais como base principal do processo de compreensão do conteúdo constitucional. A partir do momento em que apontam os postulados básicos e finalidades precípuas da Constituição, é imperiosa a conclusão de que todas as normas ali contidas direcionem-se ao conteúdo por eles espelhado.

Funcionam os princípios então como instrumentos condutores à unidade do sistema normativo constitucional. Isso porque, assim como já aduzido, dado o caráter político da Constituição, essa traz em seu teor idéias e compromissos sustentados por correntes opostas de opinião, de modo que, aparentemente, pudessem se apresentar contraditórias. É incumbência dos princípios, portanto, conduzir a exegese constitucional a uma conclusão integradora de todas as normas para um mesmo sentido.

Para fins de influência na interpretação normativa, alguns princípios possuem, ressalte-se, maior preponderância. Aponta a doutrina, então, para distinção entre os princípios constitucionais fundamentais, os gerais e os setoriais. Os primeiros

\footnotetext{
${ }^{41}$ Entende-se por pós-positivismo o conjunto de idéias intermediárias entre o estrito legalismo positivista e a razão subjetiva do jusnaturalismo, que se traduz no resgate dos valores, na reaproximação entre Direito e Ética, na relevância e busca da concretização dos Direitos Fundamentais e no reconhecimento da força normativa dos princípios.
} 
são aqueles que exprimem a ideologia política do Estado, os fundamentos da organização político-estatal. Destacam-se, dentre esses, o princípio federativo, republicano, e o da dignidade da pessoa humana. Os gerais, por sua vez, representam emanações dos fundamentais, e qualificam-se por assegurar direitos aos indivíduos, apesar de faze-lo com considerável grau de abstração. Conforme lição de Canotilho, são também denominados "princípios-garantia". ${ }^{42}$ Dentre esses, elencam-se os da isonomia e o da legalidade. Os últimos, por fim, consubstanciam um conjunto de normas referentes a um tema específico, a um ponto, parte ou capítulo determinado da Constituição. Exemplo desses seria o da legalidade tributária.

Pois bem. Inegável a maior relevância dos princípios gerais e fundamentais na busca da unidade constitucional. Em razão do teor que contém tais vetores, representam esses, na maior das instâncias, os objetivos e valores da Constituição. Segundo estatui Raul Canosa Usera, ${ }^{43}$ aliás, a correta interpretação constitucional demanda exatamente a disposição das que denomina normas de princípio em patamar superior. Por tal motivo é que se fala em hierarquia axiológica desses princípios quando da interpretação constitucional. Em outros termos, válida é a exegese que mais se aproxima do teor desses. Na ponderação do conteúdo constitucional, da mesma forma, deve a interpretação que mais deles se aproxima prevalecer.

Em resumo, portanto, todo o procedimento de interpretação das regras constitucionais, para que reste legítimo, deve ser condicionado, pautado pelos princípios nela estampados. Desconsiderados os vetores valorativos presentes na Constituição, afastada estará a compreensão de suas normas da real finalidade de seus respectivos conteúdos, o que não se pode admitir. A Constituição deve ser encarada, portanto, e assim interpretada, como um sistema, composto por regras e princípios a serem concatenados.

Com base em todo o acima exposto, há que se concluir que a regra inserta no parágrafo único do art. $7^{\circ}$ da Constituição da República Federativa do Brasil deve ser interpretada harmonicamente com os princípios nela consagrados. Dessa forma, imperioso se faz, como corolário da aplicação da idéia de unidade da constituição, e ponderando-se o conteúdo constitucional, o alcance de uma conclusão direcionada a solucionar a antinomia aparente entre esse preceito e alguns princípios materiais. Para tanto, faz-se necessário identificar em quais pontos da Constituição se situam essas antinomias. É sobre tal aspecto que se passa a dissertar.

\footnotetext{
${ }^{42}$ CANOTILHO, José Joaquim Gomes. Direito constitucional. 5. ed. Coimbra: Almendina, 1991. p. 122.

${ }^{43}$ USERA, Raul Canosa. Interpretacción constitucional y formula politica. Madrid: Centro de Estudios Constitucionales, 1988. p. 163.
} 
8.2. Dos princípios constitucionais materiais em confronto com o artigo $7^{\circ}$, parágrafo único da Lei Maior

\subsubsection{Do princípio isonômico}

Em sua obra Conteúdo Jurídico do Princípio da Igualdade, o preclaro Celso Antônio Bandeira de Mello desenvolve teoria destinada a verificar, tecnicamente, se um discrímen utilizado pelo legislador se encontra em consonância com o princípio isonômico. Para que exista tal coerência, entende tal doutrinador, então, serem necessários quatro requisitos, que elenca nos seguintes termos, verbis:

a) que a desequiparação não atinja de modo atual e absoluto, um só indivíduo;

b) que as situações ou pessoas desequiparadas pela regra de direito sejam efetivamente distintas entre si, vale dizer, possuam características, traços, nelas residentes, diferenciados;

c) que exista, em abstrato, uma correlação lógica entre os fatores diferenciais existentes e a distinção de regime jurídico em função deles, estabelecida pela norma jurídica; d) que, in concreto, o vínculo de correlação supra-referido seja pertinente em função dos interesses constitucionalmente protegidos, isto é, resulte em diferenciação do tratamento jurídico fundada em razão valiosa - ao lume do texto constitucional - para o bem público. ${ }^{44}$

Entendemos que a discriminação de tratamento dispensado aos empregados domésticos encontra-se em patente disparidade com o ideal isonômico no tocante aos três últimos elementos supramencionados.

Isso porque, na realidade, inexiste efetiva desequiparação entre empregado comum e o doméstico. Ambos laboram em regime oneroso, subordinado, comumente devendo cumprir horário de entrada e saída ao serviço, e de forma não-eventual. Em resumo, o dispêndio de energia laboral é exatamente o mesmo. O empregado doméstico sofre o mesmo desgaste físico em razão de seu labor. Não encontra vantagem concreta alguma em comparação com os demais obreiros que justifique a redução de direitos. A doutrina, a jurisprudência, e a própria vontade do constituinte, consoante já demonstrado, entendem que a diferença ora em apreciação residiria no fato de o labor doméstico não ser classificado como atividade econômica, bem como no de ser realizado em local

${ }^{44}$ MELLO, Celso Antonio Bandeira de. Conteúdo jurídico do princípio da igualdade. 3. ed. São Paulo: Malheiros, 2003. p. 41. 
que inviabilizaria sua fiscalização. Pelos fundamentos já dantes delineados, acerca da impertinência de tais argumentos, reforça-se com mais veemência ainda a tese de que, no plano concreto, carente de suporte é a discriminação atualmente dispensada a tal classe de trabalhadores.

Ademais, ainda que hipoteticamente admitida a existência e suficiência de tais distinções, parece-nos que carente seriam de correlação lógica com o discrímen que fundamentam.

Recorrendo novamente às esclarecedoras lições de Celso Antônio Bandeira de Mello, esse consigna que "tem-se que investigar, de um lado, aquilo que é erigido em critério discriminatório e, de outro lado, se há justificativa racional para, à vista do traço desigualador adotado, atribuir o específico tratamento jurídico construído em função da desigualdade afirmada". ${ }^{45}$

Ora, independentemente do cunho lucrativo da atividade, consoante nosso ponto de vista, há de se ressaltar o caráter oneroso do labor realizado pelo empregado doméstico. Imperiosa a consideração, ainda, do trabalho sob o enfoque do empregado, de seu desgaste físico, para que sejam definidos os direitos trabalhistas aos quais faz jus.

Melhor esclarecendo, não vislumbramos pertinência lógica em se desproteger o empregado doméstico do desgaste decorrente de sobrelabor, ou ainda de sua submissão a agente insalubre no trabalho, dos infortúnios de um acidente de trabalho que, diga-se de passagem, são exatamente os mesmos daqueles a que estão sujeitos os empregados comuns, única e exclusivamente em razão de o empregador não-auferir lucro por meio dessa atividade.

Tomemos como exemplo concreto a situação comparativa de uma auxiliar de limpeza, atuante no âmbito empresarial, com uma empregada doméstica. A jurisprudência pátria aponta entendimento, ainda que parcial, no sentido de reconhecer o direito ao adicional de insalubridade daquela quando entra em contato com produtos químicos, no mister de efetuar a limpeza de sanitários. É o que se extrai do seguinte julgado, cuja ementa passa-se a transcrever:

Adicional de Insalubridade - Limpeza e higienização de banheiro. É insalubre o trabalho de auxiliar de limpeza que tem como atribuição também a higienização de banheiro, sem o uso de qualquer equipamento de proteção individual, em razão do contato com agentes biológicos. Recurso não provido. (TST. Acórdão n. 221439. Decisão: 18-03-1998.

${ }_{45}$ MELlO, Celso Antonio Bandeira de. Conteúdo jurídico do princípio da igualdade. 3. ed. São Paulo: Malheiros, 2003. p. 38. 

principiológico constitucional

RR 221439. Ano: 1995. Região: 04. UF: RS. Órgão Julgador - Quarta Turma. Fonte:DJ Data: 03-04-1998. Pg: 350.

Relator: Ministro Leonardo Silva).

Consigne-se que tanto a empregada doméstica, como o auxiliar de limpeza empresarial, desempenham a mesma tarefa, fazem uso dos mesmos produtos e, portanto, colocam em risco, no mesmo grau, suas saúdes, na medida em que se submetem aos mesmos agentes insalubres. Parece-nos ilógico, nesse sentido, desproteger o doméstico em razão de seu labor não possuir cunho econômico, não gerar lucro para o empregador.

Em resumo, o que se quer demonstrar é que falta pertinência lógica para o discrímen decorrente da majoritária interpretação atual do patrimônio jurídico do empregado doméstico e dos elementos erigidos como fatos justificadores da diferenciação. Ao nosso ver, os direitos sociais assegurados no art. $7^{\circ}$ da Lei Maior buscam proteger o trabalhador, sua saúde, segurança, integridade e dignidade ao longo da vida, e não o empregador. Incoerente é tomar como base de distinção de tratamento, portanto, a natureza da relação laboral apreciada sob o aspecto desse último. Afronta o princípio da igualdade, então, o tratamento ora dispensado ao doméstico.

Insta mencionar, ainda, como reforço de argumentação, que no início das discussões acerca da construção dos direitos sociais assegurados constitucionalmente aos domésticos, evidente era a preocupação do constituinte com a proteção da saúde e segurança dessa classe, sem qualquer diferenciação. Isso porque, ainda não havia sido formado o consenso que envolvia o acima aludido suposto fator de discriminação. Assim é que, em parecer emitido sobre pedido de emenda modificativa elaborado por Luis Roberto Ponte, tendente a suprimir da redação original da Constituição o direito dos empregados domésticos ao controle de jornada (que originariamente lhes era assegurado), dispôs a comissão da ordem social que "a limitação de jornada é medida indispensável para evitar a discriminação do empregado doméstico. A peculiaridade da profissão poderá ensejar divisão do tempo total diário em intervalos diferentes dos usuais na atividade produtiva. O limite máximo a ser fixado, contudo, é frei indispensável a eventuais abusos do empregador". ${ }^{46}$

Na mesma esteira, em outro pleito de emenda, de autoria de Vilson de Souza, representante do PMDB de Santa Catarina, emitiu-se parecer no sentido de que "não se justifica impor ao empregado doméstico jornada de 48 horas semanais no momento em

${ }^{46}$ Vide Anexo n. 01 
que se assegura aos demais trabalhadores do país a redução da jornada semanal de trabalho para 40 horas". ${ }^{47}$

Como se vê, ainda nas origens da atual Constituição, não se reconhecia a existência de motivo apto a gerar discriminação entre empregado comum e doméstico. Posteriormente, veio o legislador constituinte a erigir discrímen que, nos termos acima expostos, não guarda relação lógica, suporte racional com seus fundamentos.

Válido transcrever, ainda, trecho de discurso de Osvaldo Bender, membro do PDS do Rio Grande do Sul, proferido no plenário da constituinte, aos 24-06-1987, que inconformado com a aprovação da atual redação do parágrafo único do art. $7^{\circ}$ da Constituição Federal, mormente quanto à supressão da garantia de estabilidade aos domésticos, manifestou-se nos seguintes termos:

(...) o impedimento dos mesmos direitos delegados, aos demais trabalhadores pelos radicais só se pode atribuir a uma razão, qual seja, a de eles mesmos não quererem assumir a responsabilidade pela estabilidade em seus lares. Não encontro outra resposta, a não ser esta.(...) Veja, Sr. Presidente, Sras. e Srs. Constituintes, se a estabilidade gera desemprego num setor, é evidente que o mesmo também acontece com os outros setores. Não acredito que a Constituinte fará discriminações mais uma vez entre os brasileiros.(...)Cometer a Constituinte tamanha injustiça e elaborar uma legislação paralela para as domésticas, isto é vergonhoso. ${ }^{48}$

Acresça-se, ainda, que mesmo superada toda a argumentação ora expendida, e admitida a correlação entre o contexto do labor doméstico e a redução dos direitos assegurados àqueles que o desempenham, não lograria êxito o discrímen em questão em apresentar compatibilidade com os interesses constitucionalmente protegidos.

De fato, a Constituição estabelece como fundamentos do Estado Democrático de Direito, a dignidade da pessoa humana e o valor social do trabalho. Em seu art. $3^{\circ}$, aponta como um de seus objetivos a erradicação da pobreza, da marginalização, e a redução das desigualdades sociais. E até mesmo ao tratar da ordem econômica, em seu art. 170, demonstra preocupação com o valor do trabalho humano, e com a busca de justiça social.

Dessarte, parece-nos que uma norma interpretada no sentido de se reduzir direitos mínimos assegurados aos empregados, apenas para os empregados domésticos,

\footnotetext{
47 Vide Anexo n. 02

${ }^{48}$ Diário da Assembléia Nacional Constituinte, Brasília, 24-06-1987, p. 2.845.
} 
direitos esses essenciais à garantia da dignidade desses obreiros, aponta-se tendente a contrariar o intuito de redução de desigualdades, de consecução de justiça social, e de valorizar o trabalho humano daquela classe.

Por todos os fundamentos acima delineados, concluímos que a corrente exegese dada ao dispositivo constitucional que versa sobre os direitos garantidos aos empregados domésticos não se encontra em paridade com o princípio isonômico.

\subsubsection{Do princípio do valor social do trabalho}

Conforme já exposto, a Constituição da República Federativa do Brasil traz, dentre os fundamentos do Estado brasileiro, a crença nos valores socais do trabalho. De tal disposição, extrai-se que o trabalho deve sempre ter seu valor reconhecido, através de justa remuneração, e de condições razoáveis para seu desenvolvimento.

Celso Ribeiro Bastos, ao apreciar os fundamentos do Estado Democrático de Direito, assevera que esses "devem ser entendidos como embasamento do Estado; seus valores primordiais, imediatos, que em momento algum podem ser colocados de lado". ${ }^{49}$ Seguindo a mesma inteligência, Luis Roberto Barroso dispõe que a consecução de tais fundamentos deve "figurar como vetor interpretativo de toda a atuação dos órgãos públicos". 50

A valorização do trabalho, consoante nosso entendimento, inclui, além da justa remuneração, o reconhecimento de sua importância social, bem como sua não discriminação. Uma vez demonstrada a disparidade do tratamento jurídico atualmente dispensado ao empregado doméstico perante o princípio da igualdade, resulta como corolário lógico configurada, nesse mister, igualmente, inobservância ao valor social do trabalho.

\subsubsection{Do princípio da dignidade da pessoa humana}

Apesar do alto grau de abstração do princípio em tela, sua consideração, no procedimento exegético a que ora nos propomos, é de suma importância.

Com vistas a se delimitar o conceito de dignidade da pessoa humana, pode-se dizer que ela "expressa um conjunto de valores civilizatórios incorporados ao patrimônio da humanidade. O conteúdo jurídico do princípio vem associado aos direitos

\footnotetext{
49 BASTOS, Celso Ribeiro. Curso de direito constitucional. 20. ed. São Paulo: Saraiva, 1999. p. 158.

${ }^{50}$ BARROSO, Luis Roberto. Interpretação e aplicação da Constituição. 6. ed. São Paulo: Saraiva, 2004. p. 140 .
} 
fundamentais, envolvendo aspectos de direitos individuais, políticos e sociais. Seu núcleo material elementar é composto do mínimo existencial, locução que identifica o conjunto de bens e utilidades básicas para a subsistência física e indispensável ao desfrute da própria liberdade. Aquém daquele patamar, ainda quando haja sobrevivência, não há dignidade". ${ }^{51}$

Recorrendo novamente às precisas colocações de Celso Ribeiro Bastos, tal princípio "visa condenar práticas como a tortura, sob todas as suas modalidades, o racismo e outras humilhações tão comuns no dia-a-dia de nosso país". De certo, dentre as práticas elencadas pelo insigne autor, não apenas o racismo, como toda e qualquer forma de discriminação se encontram inclusas nos atos afrontadores à dignidade humana.

Nota-se, portanto, que o princípio em questão resta atendido apenas quando observados os outros dois ideais acima já expostos, bem como todos os outros valores humanos fundamentais reconhecidos por nossa Constituição. Nessa esteira, somente poderá ser considerado como digno o trabalho desempenhado em moldes isonômicos quando comparados aos demais ofícios, e que garanta o mínimo justo remuneratório. É digno, em outras palavras, o trabalho que tem seu valor efetivamente reconhecido.

A desconsideração do desgaste corpóreo ao qual é submetido o empregado doméstico, e a conseqüente restrição dos direitos que lhe são assegurados, sem qualquer motivo suficientemente válido para justificar tal discriminação, por representar desvalorização social de tal trabalho, e portanto ao princípio isonômico, resulta também em afronta à dignidade da pessoa humana.

Insta considerar, ainda, que tal princípio foi erigido constitucionalmente, no texto ora em vigor, à categoria de fundamento do Estado Democrático de Direito. Jamais poderia, portanto, ser desprestigiado, devendo qualquer atividade legislativa e jurisdicional buscar a consecução de tal ideal.

8.3. Da interpretação adequada à regra restritiva em face de todo o conteúdo constitucional

As referidas premissas teóricas, detalhadas anteriormente, compõem suporte jurídico para se considerar existente antinomia entre o teor do art. $7^{\circ}$, parágrafo único da Constituição Federal, nos moldes em que é interpretado ultimamente, e o conteúdo principiológico constitucional. Nota-se, outrossim, que assim como já comentado, os princípios não mais têm sua função limitada unicamente à inspiração do legislador.

${ }_{51}$ BARROSO, Luis Roberto. Interpretação e aplicação da Constituição. 6. ed. São Paulo: Saraiva, 2004. p. 335. 
Possuem eles força normativa, devendo ser observados na aplicação do direito ao caso concreto, e conseqüentemente, no trabalho do exegeta constitucional. Até porque, a aplicação do direito nada mais representa que a última etapa do processo interpretativo.

Pois bem. A Constituição Federal aponta como princípio fundamental do Estado Democrático de Direito o da proteção da dignidade da pessoa humana. Desenha como um de seus objetivos fundamentais o da valorização social do trabalho. E assegura, como direito fundamental do cidadão, o da igualdade. Em outras palavras, contempla em larga escala normativa o princípio isonômico.

Consoante anteriormente demonstrado, a mera interpretação gramatical do art. $7^{\circ}$, parágrafo único da Constituição Federal não se coaduna com os princípios ora em comento. Como visto, inexiste motivo concreto, real, que torne necessária a diferenciação do empregado doméstico perante o trabalhador comum. Mesmo que, hipoteticamente, a título de argumentação, admitida fosse a existência de tais diferenças, ausente seria qualquer correlação lógica entre a discriminação de tratamento dispensado ao doméstico, e os fatos comumente apontados como seus justificadores. E por fim, ainda que vislumbrada tal pertinência lógica, tal discrímen falharia na subsunção de seu teor aos ditames de uma Constituição-cidadã, dotada de marcante preocupação com a ordem e a justiça social.

Incontestavelmente, a redução dos direitos assegurados aos empregados domésticos sem qualquer justificativa plausível, afasta-se da valorização social do trabalho desempenhado por essa classe de obreiros, donde se extrai o descompasso da regra em apreciação com também esse outro princípio.

Como conseqüência, presente o tratamento não isonômico, e a desvalorização da energia laboral do doméstico, inegável é o desrespeito de sua dignidade enquanto ser humano.

Inadmissível se extrai, portanto, perante toda a ordem principiológica que permeia a Constituição, a interpretação literal do supramencionado dispositivo que enumera o rol de direitos cabíveis aos domésticos. Reitera-se, entretanto, que como regra de hermenêutica constitucional, tal conflito deve ser encarado como mera antinomia aparente. Assim sendo, para que seja resgatada a unidade da Constituição, necessária se faz uma nova exegese do parágrafo único de seu art. $7^{\circ}$. Uma interpretação sistemática que compatibilize efetivamente os princípios constitucionais com a regra em questão.

Por todo o acima exposto, a única conclusão possível de ser extraída é a de que os ideais de dignidade da pessoa humana, valor social do trabalho e igualdade seriam atendidos apenas se igualada a proteção legal dos domésticos àquela conferida aos demais 
empregados. O enfoque tradicional dado à regra aparentemente restritiva merece, então, ser alterado.

Nesse sentido, procedida uma análise constitucional sistemática baseada em princípios, possível se faz concluir que a vontade constitucional, a concretização dos valores ali estatuídos, só seria possível se efetivamente equiparado fosse o tratamento jurídico dispensado aos trabalhadores comuns e aos domésticos. Assim sendo, imperioso seria o entendimento de que a regra inserta no parágrafo único do art. $7^{\circ}$ demanda uma relativização de sua literalidade, para que seja considerada como apontadora de mero rol não exaustivo de direitos. E como consectário lógico, aos domésticos, na realidade, e por decorrência da unidade da constituição, seriam assegurados todos os direitos garantidos aos empregados comuns. Essa sim seria a correta exegese, baseada no instrumental hermenêutico específico para a compreensão do texto constitucional.

Para tanto, válido seria se apreciar com maior apego a redação do caput do art. $7^{\circ}$ da Constituição Federal, pela qual se percebe que ali se encontram arrolados os direitos assegurados aos trabalhadores, "além de outros que visem a melhoria de sua condição social'. Ressaltamos essa última expressão. Uma exegese conjunta do teor do referido caput com o parágrafo único do mesmo artigo, até porque há que se admitir que um subitem legal deve ser compreendido no contexto da regra geral trazida pelo caput, permitiria a conclusão de que também aos trabalhadores empregados domésticos seriam assegurados os direitos ali especificados, além de outros que garantam a melhoria de sua condição social.

Recorrendo-se novamente à interpretação histórica, aliás, é de se verificar que quando da discussão, em sede de Assembléia Constituinte, acerca da redação a ser dada ao parágrafo único do já mencionado art. $7^{\circ}$, projetos buscavam incluir aquela mesma expressão em seu texto. ${ }^{52}$ Não se trataria, em suma, de rol taxativo, que naqueles termos esgotasse a proteção dispensada a tal classe de trabalhadores. Tratar-se-ia, meramente, de rol exemplificativo, passível portanto de ampliação para incorporar qualquer outra garantia compatível com o labor doméstico, e destinada à melhoria da condição social desses obreiros. Assim, poder-se-ia considerar aplicáveis todos os incisos do art. $7^{\circ}$ à relação de emprego doméstico.

Conseqüentemente, e até como emanação do princípio da supremacia da Constituição, os preceitos normativos insertos na Consolidação das Leis do Trabalho, e também na Lei n. 5.859/72, que previam a distinção de regime jurídico em detrimento

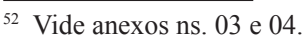


do empregado doméstico, seriam tidos como não-recepcionadas pelo novo regime constitucional instituído a partir de 1988, e portanto, teriam sua eficácia esgotada.

Acresça-se, ainda, que em colaboração com todo o acima expendido, encontram-se os já referidos instrumentos de direito internacional, como tratados e convenções, devidamente ratificados pelo Brasil, e que não fazem distinção de tratamento para o empregado doméstico. Aliás, consoante entendimento sustentado por abalizada doutrina, dentro da qual destacamos a lição de Flávia Piovesan, ${ }^{53}$ tais tratados internacionais, ratificados pelo Brasil, por versarem sobre direitos humanos, por força do teor do art. $5^{\circ}, \S \S 2^{\circ}$ e $3^{\circ}$ da Lei Maior, ingressariam na ordem jurídica pátria com força constitucional. Mais incoerente ainda seria, então, considerar vigentes tais normas em grau constitucional, juntamente com a literal redação do art. $7^{\circ}$, parágrafo único.

Da mesma forma, aprovado o projeto de conversão de Medida Provisória em Lei antes referido, maior ainda se apresenta a contribuição teórica e legislativa para a defesa do ora sustentado. Isso porque, se convolado em lei o referido projeto, após aprovação em ambas casas legislativas, o que pressupõe inclusive a análise, em suas comissões competentes, da constitucionalidade do teor da nova lei, claro resta que efetivamente não existe motivo suficiente para justificar a diferenciação até então empregada. Factível, portanto, é o alcance da igualdade de tratamento entre empregado comum e doméstico, tanto quanto o foi a majoração de direitos. Reitera-se, nesse sentido, então, que a evolução legislativa até então alcançada não é suficiente. Não pode o regime jurídico do doméstico se esgotar nas conquistas trazidas pela Lei n. 11.324/2006. Imperiosa se faz a plena equiparação de direitos.

Defende-se, portanto, que por meio de tal exercício exegético, é possível proceder a aplicação, em âmbito de labor doméstico, dos preceitos assecuratórios de limite de jornada laboral, de inscrição no Fundo de Garantia por Tempo de Serviço, de indenização por despedida arbitrária ou sem justa causa, de garantia provisória de emprego quando da ocorrência de acidente de trabalho e doença profissional, de período de férias com duração de trinta dias, e também de proteções asseguradas na CLT, tais como as previstas em seus arts. 467 , e $477, \S 8^{\circ}$ desse diploma legal. Equiparados seriam os regimes jurídicos.

Reitera-se, ainda, que questões instrumentais, referentes à viabilidade de operacionalização e fiscalização do cumprimento de tais direitos representam pontos secundários, cuja solução pode ser facilmente alcançada pela criatividade humana, que já se provou capaz de solucionar impasses de maior complexidade que esse para a sociedade.

53 PIOVESAN, Flávia. Direitos humanos e direito constitucional internacional. 3. ed. São Paulo: Max Limonad, 1997. p. 89. 
O que se quer transmitir é que não se faz impossível a realização de controle de jornada em âmbito residencial, tampouco de fiscalização domiciliar do cumprimento de obrigações juslaborais. Basta que sejam criadas regras destinadas a adaptar tais necessidades às peculiaridades de tal ambiente de trabalho.

Igualmente, não se justificam os receios que circundam a ampliação dos direitos assegurados aos domésticos, como os de que tal fato gerará a ampliação dos índices de desemprego, ou acarretará violação à intimidade do núcleo familiar. Com relação ao aspecto econômico, como já explanado, merece esse ser de plano rechaçado, vez que jamais representaria suporte para justificar a relativização de direitos sociais.

No tocante à intimidade, insta se esclarecer que a aplicação de dispositivos como, por exemplo, os assecuratórios de garantia de emprego aos domésticos, de certo deveria ser efetuado dentro de parâmetros de razoabilidade, proporcionalidade e bom senso. Exatamente como é procedido em âmbito empresarial. Melhor esclarecendo, quando indesejada a permanência do obreiro doméstico no trabalho, e quando acobertado esse por proteção contra dispensa injustificada, patente será o embate entre bens jurídicos, quais sejam a dignidade do trabalhador, de um lado, e a intimidade do núcleo familiar, bem como também a dignidade de seus membros.

Tal conflito, assim como já esclarecido, deverá ser solucionado concretamente pela aplicação do método da ponderação, na qual o julgador, efetuando a compressão mútua dos bens em conflito, destinada a alcançar a efetividade máxima de cada um no caso concreto, buscará, dentro de padrões razoáveis, solucionar a pendência. Assim sendo, e como ocorre também em âmbito de relações empregatícias fora da esfera familiar, perfeitamente aceitável seria a solução de, com vistas a se evitar desgastes aos interesses fundamentais da família empregadora, bem como maior detrimento à dignidade obreira, decorrente da manutenção do emprego em condições insustentáveis, se fixar uma indenização justa e suficiente para possibilitar o trabalhador a superar a dificuldade ensejadora de sua garantia de emprego que, dadas as peculiaridades da situação, veio a transacionar.

Em suma, a unidade da constituição, decorrente da harmonização da regra inserta no parágrafo único de seu art. $7^{\circ}$, com o conteúdo principiológico da Lei Maior é medida que se impõe. Por isso é que sustentamos a exegese ora exposta. Às questões de importância secundária, de certo seriam encontradas soluções pelos órgãos de fiscalização, pela doutrina e pela jurisprudência. Tais fatores, contudo, jamais seriam aptos a obstaculizar a efetivação dos ideais de igualdade, dignidade humana e valorização social do trabalho, primados essenciais almejados pela ordem constitucional. 
9. Conclusão

Ao longo do presente trabalho, buscamos demonstrar as peculiaridades atinentes ao regime jurídico assegurado ao trabalhador empregado doméstico.

Trouxe-se à baila elementos destinados a evidenciar as raízes históricas dessa espécie de labor. Buscou-se, ainda, expor as principais características da relação empregatícia doméstica, com especial enfoque nos elementos que a diferenciam do contrato de trabalho que envolva um empregado comum.

Delineou-se, ainda que brevemente, quais direitos são incorporados pela legislação vigente ao patrimônio dos empregados domésticos, bem com quais não se encontram especificamente conferidos.

Intentou-se, ainda, apontar os principais elementos e fundamentos sustentados pela doutrina e pela jurisprudência, com vistas a se justificar o tratamento protetivo diferenciado dispensado à classe obreira em questão.

Posteriormente, procurou-se demonstrar a incompatibilidade desse tratamento discriminatório com o conteúdo principiológico constitucional ora componente e inspirador de toda a ordem jurídica vigente. Evidenciou-se a disparidade entre a majoritária interpretação atribuída ao art. $7^{\circ}$, parágrafo único da Constituição da República Federativa do Brasil e os princípios da igualdade, da valorização social do trabalho, e em suma, da dignidade da pessoa humana.

Com base em tais fundamentos, sugeriu-se uma nova interpretação constitucional, não limitada à literalidade do preceito supramencionado, mas que compute, também, aqueles princípios acima elencados, além das normas internacionais, tanto os documentos históricos, como as atualmente ratificadas pelo Brasil, assecuratórios da igualdade de tratamento no trabalho como fator de proteção dos direitos humanos.

Feitas tais considerações, torna-se possível o vislumbrar de conclusões acerca do tema em debate, as quais passam a ser transcritas.

Latente é a ligação histórica do trabalho doméstico com a escravidão. É nesse regime de trabalho atentatório aos preceitos mínimos de direitos humanos que se encontra a raiz do labor em tela.

A sociedade, contudo, influenciada por ideais iluministas, humanistas, presenciou revoluções, lutas pela quebra de estados de fato, que importaram em grande evolução. Nesse contexto é que se progrediu, em geral, do trabalho indigno para o assalariado, atencioso às necessidades dos obreiros. 
A ordem jurídica supranacional, igualmente, por meio de instrumentos de direito internacional, como tratados e convenções, reconhece como instrumento indispensável para a concretização dos direitos humanos fundamentais a proteção do trabalhador contra os riscos e desgastes inerentes ao dispêndio de energia laboral. Nesse mister, em sua grande maioria, não faz restrição quanto ao campo de incidência de tal proteção. Abrange os trabalhadores em geral. Não exclui, assim, os domésticos.

Toda essa evolução, todavia, parece não ter sido suficiente para quebrar estigmas culturais ainda influenciadores do comportamento humano, mormente em âmbito brasileiro.

Tanto o referido é verdade que, a despeito do reconhecimento, inclusive em sede constitucional, da importância do respeito à igualdade e dignidade dos indivíduos, em todos os setores da vida, inclusive no trabalho, permanecem submetidos os empregados domésticos a tratamento discriminatório, em comparação àquele dispensado aos empregados comuns.

Incontestável é a insuficiência dos argumentos sustentados para justificar a restrição dos direitos conferidos aos domésticos. Ademais, por maior esforço interpretativo que se possa efetuar, ao nosso ver, jamais preponderariam esses quando ponderados com todo o conteúdo de princípios e valores presente na Constituição Federal ora em vigência, e portanto conducentes de toda a exegese e validade da ordem infraconstitucional.

Contribui, como reforço de argumentação para o ora sustentado, o fato de o Poder Legislativo, por meio do Senado Federal, e com a correspondente aprovação da Câmara dos Deputados, elaborar emendas sobre o referido projeto de conversão de Medida Provisória em Lei, com vistas a se ampliar o rol de direitos garantidos à classe doméstica. A sanção presidencial, mesmo que parcial, auxilia na idéia de que realmente a diferenciação de direitos conferidos aos domésticos e aos demais empregados não se justifica.

Melhor esclarecendo, o êxito em tal tramitação legislativa permite concluir que o suporte jurídico direcionado à interpretação constitucional que ora se propõe é substancial, é válido. Independentemente da finalidade almejada pelo Congresso Nacional quando da apresentação de tal proposta normativa, nota-se que presente vontade política, factível é a ampliação do regime jurídico dos domésticos. Ausente tal vontade do legislador, como se verificou até o presente momento de nossa história, o que se vislumbra é indevida discriminação de tratamento.

O trabalho doméstico se apresenta como uma das mais recorridas ocupações produtivas no Brasil, principalmente para as mulheres. Crescente também é a presença 
dos homens nesse mercado, na atualidade, em face da extrema dificuldade de se alcançar uma colocação profisssional em demais setores. Inegável, então, é o impacto social desse tratamento diferenciado e injustificado ora vigente, vez que atinge, no cerne da dignidade da pessoa humana, relevante e considerável parcela dos cidadãos ativos.

Imperiosa se faz, portanto, a quebra dos preconceitos arraigados na cultura dos indivíduos, para que passe a ser reconhecida a inexistência de qualquer diferença entre os riscos e desgastes sofridos por um empregado atuante em atividade lucrativa para seu empregador, e o obreiro doméstico. Vislumbrada tal paridade, torna-se possível o reconhecimento da idêntica importância do trabalho doméstico como engrenagem social. Alcançado tal patamar, tornar-se-á mais injustificada ainda a manutenção de qualquer discriminação, quanto à garantia de direitos assegurados aos obreiros em questão.

De incontestável importância mostram-se os esforços doutrinários, no sentido de se buscar construir, dentro da égide do atual enfoque dado ao art. $7^{\circ}$, parágrafo único do texto constitucional, entendimentos destinados a se conferir uma ou outra garantia aos trabalhadores domésticos, tais como a estabilidade no emprego à gestante, ou a duração de trinta dias de férias.

Ao nosso ver, contudo, qualquer parcial ampliação não se apresenta suficiente para a superação do preconceito enraizado. Seria indispensável uma total mudança no enfoque da regra constitucional, atualmente interpretada como restritiva de direitos, para que passasse essa a ser enxergada como meramente exemplificativa, e passível de extensão, a todo o conteúdo descrito pelos incisos desse mesmo dispositivo constitucional, que se encaixe no contexto do trabalho doméstico. Tal esforço hermenêutico, decorrente da mera e correta aplicação sistemática do conteúdo constitucional, reconhecedora da unidade desse sistema, possibilitaria ainda se reconhecer como não recepcionados pela ordem vigente os dispositivos infraconstitucionais que não se enquadrem nos parâmetros principiológicos ora descritos. Dentre eles, as regras da Lei n. 5.859/72, e seu respectivo Decreto regulamentador, atinentes à redução do valor e número de parcelas do segurodesemprego, e da mera facultatividade do regime do FGTS, além daquela inserta no art. $7^{\circ}$, "a" da CLT, que exclui os domésticos de sua esfera de proteção.

Repita-se, ainda, que questões econômicas, ou meramente operacionais para a concretização desses direitos no plano fático não merecem ser consideradas como óbices à concretização dos direitos sociais fundamentais em questão. Até porque, a implementação desses, de certo, merece ser entendida como objetivo primordial do Estado Democrático de Direito, vez que se consubstancia em medida destinada a atender as finalidades descritas no art. $3^{\circ}$ da Constituição Federal. 
Em suma, há que se atentar para o fato de que toda a operação legislativa, jurisdicional, e toda a exegese da ordem jurídica vigente devem pautar-se e direcionarse à concretização da vontade constitucional. Afasta-se dessa a existência de qualquer indevido tratamento antiisonômico. Com base em todo o acima exposto, então, conclui-se que apenas por meio do reconhecimento da incoerência da regra restritiva dos direitos assegurados aos empregados domésticos, e sua conseqüente superação é que se alcançará tal finalidade, vez que concretizados restarão os ideais de igualdade, respeito ao valor social do trabalho, e como corolário lógico, de dignidade da pessoa humana.

São Paulo, novembro de 2007.

10. Anexos

10.1. Anexo 01

Bases Históricas do Congresso Nacional

Fonte: Secretaria-Geral da Mesa

Banco de Emendas. Base de pesquisa: Anteprojetos, Projetos e Emendas da Assembléia Nacional Constituinte de 1988 (APEM)

Fase: G-Emenda ao Substitutivo do Relator da Comissão

Comissão: VII-Comissão da Ordem Social

Emenda n. 00103

Apresentação: 09-06-1987

Situação: Rejeitada

Autor: PDS-Roberto Campos

Texto: "Suprima-se o item III do art. $3^{\circ}$ do Substitutivo"

Parecer: Rejeitada. A limitação de jornada é medida indispensável para evitar a discriminação do empregado doméstico. A peculiaridade da profissão poderá ensejar divisão do tempo total diário em intervalos diferentes dos usuais na atividade produtiva. O limite máximo a ser fixado, contudo, é freio indispensável a eventuais abusos do empregador. 
Dos direitos do empregado doméstico. Incoerência da interpretação restritiva em face do conteúdo principiológico constitucional

\subsection{Anexo 02}

Bases Históricas do Congresso Nacional

Fonte: Secretaria-Geral da Mesa

Banco de Emendas. Base de pesquisa: Anteprojetos, Projetos e Emendas da Assembléia Nacional Constituinte de 1988 (APEM)

Fase: G-Emenda ao Substitutivo do Relator da Comissão

Comissão: VII - Comissão da Ordem Social

Emenda n. 01054

Apresentação: 09-06-1987

Situação: Rejeitada

Autor: PMDB - Vilson Souza

Texto: "Dá nova redação ao inciso III do artigo $3^{\circ}$ do Substitutivo da Comissão da Ordem Social: III - Limitação de jornada de trabalho a 48 horas semanais”,

Parecer: Rejeitada. Não se justifica impor ao empregado doméstico jornada de 48 horas semanais no momento em que se assegura aos demais trabalhadores do país a redução da jornada semanal de trabalho para 40 horas.

\section{3. Anexo 03}

Bases Históricas do Congresso Nacional

Fonte: Secretaria- Geral da Mesa

Banco de Emendas. Base de pesquisa: Anteprojetos, Projetos e Emendas da Assembléia Nacional Constituinte de 1988 (APEM)

Fase: $M$-Emendas ao Projeto de Constituição

Comissão: IX-Comissão de Sistematização

Emenda n. 13909

Apresentação: 13-08-1987

Situação: Parcialmente Aprovada

Autor: PT-João Paulo 
Texto: "Inclua-se no Projeto de Constituição, onde couber, no Título II, Capitulo II:

Art. $1^{\circ}$. A Constituição assegura aos trabalhadores, independente de Lei, os seguintes direitos, além de outros que visem melhoria de sua condição de empregado doméstico no quadro social, ressaltando sua condição inequivoca de trabalhador:

I - Reconhecimento de sua categoria profissional pelo Ministério do Trabalho com acesso às disposições da Legislação Previdenciária e Trabalhista Consolidadas;

II - Elevação da condição de Associação Profissional em Sindicato de Classe com todas as prerrogativas que a Legislação Sindical confere;

III - Salário Mínimo real, nacionalmente unificado, capaz de satisfazer às necessidades integrais, a ser fixado pelo Congresso Nacional;

IV - Salário família à razão de $20 \%$ (vinte por cento) do salário mínimo vigente, para filho ou dependente menor de 14 (quatorze) anos e ao conjuge e filho menor de 21 (vinte e um) anos, desde que não exerçam atividades econômicas e ao filho inválido de qualquer idade;

$V$ - Salário de trabalho noturno superior ao diurno em pelo menos 50 (cinqüenta por cento), independente de revezamento, compreendendo o horário das 18:00 (dezoito) às 6:00 (seis) horas, sendo a hora noturna de 45 minutos;

$V I-13^{\circ}$ (décimo terceiro) salário com base na remuneração integral, pago em dezembro de cada ano;

VII - Alimentação custeada pelo empregador servida no local de trabalho;

VIII - Reajuste mensal de salários, remunerações e pensões pela variação do índice do custo de vida;

IX - Duração máxima da jornada de 8 (oito) horas diárias e 40 (quarenta) horas semanais com intervalo para repouso e alimentação;

$X$ - Remuneração de forma dobrada nos serviços extraordinários, emergenciais ou de força maior;

$X I$ - Repouso remunerado aos sábados, domingos e feriados, civis e religiosos de acordo com a tradição local, garantindo o repouso de pelo menos com a tradição local, garantindo o repouso de pelo menos dois fins de semana ao mês;

XII - Férias anuais com gozo de pelo menos 30 (trinta) dias com pagamento igual ao dobro da remuneração mensal;

XIII - Estabilidade no serviço desde a data de ingresso, salvo cometimento de falta grave comprovada judicialmente;

$X I V$ - Fundo de garantia por tempo de serviço que poderá ser levantado pelo trabalhador em qualquer caso de rescisão do contrato de trabalho; 

principiológico constitucional

XV - Assegurado ao trabalhador o direito de greve, sem qualquer restrição na Legislação.

XVI-Higiene e segurança no trabalho. Proibição de diferença de salário por trabalho igual inclusive nos casos de substituição ou sucessão do trabalhador, bem como proibição de diferença de critérios de admissão por motivo de raça, cor, credo, opinião pública, militância sindical, nacionalidade, idade, estado civil, origem, deficiência física, condição social ou outros motivos discriminatórios;

XVII - Proibição de exploração do trabalho do menor como pretexto de criação e educação, de sua prestação em jornada noturna aos menores de 18 (dezoito) anos;

XVIII - Proibição de prestação de serviços em atividades perigosas ou insalubres alheias à natureza de sua condição de empregado doméstico;

XIX - Proibição de distinção de direitos por trabalho manual, técnico, ou intelectual, quanto à condição de trabalhador ou entre profissionais respectivos;

$X X$ - Não incidência de prescrição no curso do contrato de trabalho, até dois anos de sua cessação.

$X X I$ - Seguro desemprego até a data de retorno à atividade, para todo trabalhador;

XXII - Cômputo integral de qualquer tempo de serviço comprovado não concomitante, prestado em setores públicos e privados, para todos os efeitos".

Parecer: A presente emenda traz contribuições valiosas que deverão ser levadas em consideração no sentido de aprimorar o texto do Projeto. Devemos atentar para o fato, porém, que os princípios que deverão figurar no artigo 13 não podem ser protecionistas e muito menos facciosos. Visam, unicamente, estabelecer as linhas fundamentais de uma inter-relação positiva que conduza a uma integração de interesses de ambas as partes, isto é, patrão e empregado. Finalmente, o não aproveitamento total da emenda decorre do fato de estarmos preocupados em elaborar um texto que espelhe o consenso extraído das milhares de sugestões apresentadas à nossa Comissão.

\subsection{Anexo 04}

Bases Históricas do Congresso Nacional

Fonte: Secretaria- Geral da Mesa

Banco de Emendas. Base de pesquisa: Anteprojetos, Projetos e Emendas da Assembléia Nacional Constituinte de 1988 (APEM)

Fase: G-Emenda ao Substitutivo do Relator da Comissão

Comissão: VII - Comissão da Ordem Social

Emenda $n .01345$

Apresentação: 09-06-1987 
Situação: Rejeitada

Autor: PMDB - Abigail Feitosa

Texto: "Capítulo I - Dos Trabalhadores e Servidores Públicos. O art. $2^{\circ}$ passa a ter a seguinte redação: São asseguradas aos trabalhadores urbanos, rurais, inclusive os domésticos e aos servidores públicos federais, estaduais e municipais, os seguintes direitos, além de outros que visem à melhoria de sua condição social”.

Parecer: Rejeitada. Se acrescentarmos a categoria dos trabalhadores domésticos o caput deste artigo, dar-se-ia a estes os mesmos direitos das outras categorias. Entretanto, isso é inviável pelo fato que o trabalho do empregado doméstico contém certas características tão específicas que são impossiveis de serem enquadradas, na sua totalidade, no rol dos direitos enumerados no artigo $2^{\circ}$. Não desejamos com isso afirmar que eles não devam ter todos os direitos dos demais trabalhadores. Por outro lado, entendemos que o art. $3^{\circ}$ dispõe de maneira realista os princípios que devem reger o seu trabalho.

\section{Referências}

ALGRANTI, Leila Mezan. História da vida privada no Brasil: cotidiano e vida privada na América portuguesa. Organização Laura de Mello e Souza. São Paulo: Companhia das Letras, 1997.

BARROSO, Luís Roberto. Interpretação e aplicação da Constituição. 6. ed. São Paulo: Saraiva, 2004.

BAStOS, Celso Ribeiro. Comentários à Constituição do Brasil. São Paulo: Saraiva, 1989. v. 2.

Curso de direito constitucional. 20. ed. São Paulo: Saraiva, 1999.

CANOTILHO, José Joaquim Gomes. Direito constitucional. 5. ed. Coimbra: Almendina, 1991.

DELGADO, Maurício Godinho. Curso de direito do trabalho. 4. ed. São Paulo: LTr, 2005.

FERRAZ, Fernando Bastos. Empregados domésticos. 1. ed. São Paulo: Ltr, 2003.

FRÓES, Maria Helena Xavier Mendes. Trabalho doméstico. Revista Direito, Estado e Sociedade, Rio de Janeiro, n. 16, p. 01-25, 2000.

GAUGLIANO, Pablo Stolze; PAMPLONA FILHO, Rodolfo. Novo curso de direito civil. 4. ed. São Paulo: Saraiva, 2003. v. 1.

MAGANO, Octavio Bueno. Manual de direito do trabalho. 2. ed. São Paulo: Ltr, 1992. v. 2.

MARTINS, Sergio Pinto. Manual do trabalho doméstico. 3. ed. São Paulo: Atlas, 1998. 
. Direito do trabalho. 17. ed. São Paulo: Atlas, 2003.

MELLO, Celso Antonio Bandeira de. Conteúdo jurídico do princípio da igualdade. 3. ed. São Paulo: Malheiros, 2003.

. Elementos de direito administrativo. São Paulo: Revista dos Tribunais, 1991.

NORMANDO, Cláudia Cavalcante. Trabalho doméstico: valores jurídicos e dignidade humana. 1. ed. Porto Alegre: Sergio Antonio Fabris Editor, 2005.

NUNES, Luis Antônio Rizatto. Manual de introdução ao estudo do direito. 1. ed. São Paulo: Saraiva, 1996.

PIOVESAN, Flávia. Direitos humanos e direito constitucional internacional. 3. ed. São Paulo: Max Limonad, 1997.

RODRIGUEZ, Américo Plá. Princípios de direito do trabalho. 3. ed. São Paulo: LTr, 2004.

RUSSOMANO, Mozart Victor. Comentários à CLT. Rio de Janeiro: Forense, 1982.

SANTOS, Aloysio. Manual de contrato de trabalho doméstico. 2. ed. Rio de Janeiro: Forense, 1998.

SARMENTO, Daniel. Direitos fundamentais e relações privadas. São Paulo: Malheiros, 2004.

SILVA, José Afonso da. Curso de direito constitucional positivo. 24. ed. São Paulo: Malheiros, 2005.

SOUTO MAIOR, Jorge Luiz. O direito do trabalho como instrumento de justiça social. São Paulo: LTr, 2000.

SUSSEKIND, Arnaldo; MARANHÃO, Délio; VIANNA, Segadas. Instituições de direito do trabalho. 14. ed. Rio de Janeiro: LTr ,1993.

USERA, Raul Canosa. Interpretacción constitucional u formula politica. Madrid: Centro de Estudios Constitucionales, 1988. 